\title{
GOVERNMENT CONTRACTS: EMPHASIS ON GOVERNMENT
}

\author{
J. W. Whelan* aNd J. T. Phillits $\dagger$
}

It seems to me (and I think many people will share my view) that in studying the contracts of the federal government most of us are really studying government, government institutions, and public policies as much as we study agreements and contracts. In doing this our studies have not led us to any clear-cut forms of analysis and have not developed any criteria by which we can evaluate our success or lack of it in stating the fundamental problems. Some attempts have indeed been made ${ }^{1}$ but most studies in government contracts have directed themselves at the particular implications of a new statute or regulation or decision. I should say at once that I do not depreciate the usefulness of such studies.

More is needed, I believe, in the way of a fundamental rationalization of what we actually have under consideration when we lay emphasis, as we so often do, on the government in "government contracts." The remarks that follow are an attempt to probe into the "area beyond" and represent an academician's notions about some areas of inquiry which I think should be more cultivated than they are. I hope that these ideas are not dismissed with that ineffable phrase "purely academic," but I realize that they may well be subjected to that obloquy. I hope further that the reader will not mind the relative de-emphasis of judicial pronouncements; but as he reads on, I am sure that he will realize why this de-emphasis has taken place.

\section{A Short Prolegomenon}

In order to reflect the possibility and suitability of some new areas of concern for the government contract lawyer and the law teacher interested in the subject, I should like to provide a brief and summary outline of some of the subjects on which I concentrate in the course in Government Contracts. ${ }^{2}$ I should also state my belief that most of these subjects also reflect somewhat broader areas of concern: i.e., in so

- LL.B. I948, Georgetown University. Professor of Law, Georgetown University Law School.

Professor Whelan wishes to acknowledge the generosity of the Ford Foundation which has granted him a Faculty Fellowship in Law and Public Affairs. Studies made to date under this grant have led to the greater part of the ideas appearing in this paper. Ford is thus responsible but not to blame.

f An assistant to Professor Whelan who participated in the preparation of portions of this article.

${ }^{I}$ See Whelan \& Pearson, Underlying Values in Government Contracts, Io J. PuB. I. 298 (1962); Miller, Administration by Contract: A New Concern for the Administrative Lawyer, 36 N.Y.U. L. REV. 957 (196I); Hannah, Government by Procurement, 18 Bus. Law. 997 (1963).

II have taught courses in government contract law since $195 \mathrm{I}$, including courses at the Army Judge Advocate General's School during 1951-55 and at various law schools since that time. The course I teach presents the distillation (for better or worse) of these several years' experience. 
far as they reveal the operations of government generally, not only government contracts but also as in other fields, they are susceptible of use for the purpose of analyzing government operations as a whole. For a different sort of analysis, I suggest to the reader an article by Edwin Pearson and this author. ${ }^{3}$

My course in government contracts begins with an attempt to set out some of the important facts about government contracting which make it different from contracts between private parties. Among the things treated: ( $\mathrm{I}$ ) the importance of certain public officers who have statutory functions which relate, among other things, to contracts. Such officers include the heads of departments and agencies, ${ }^{4}$ the Attorney General, ${ }^{5}$ the Comptroller General. ${ }^{6}$ (2) In addition to such officers, inferior officers of the executive departments and agencies who have contract functions are mentioned. These officers are sometimes given authority by statute ${ }^{7}$ but more frequently by delegation from their superiors. ${ }^{8}$ (3) In connection with both

${ }^{8}$ See Whelan \& Pearson, supra note I.

'E.g., the Administrator of the National Aeronautics and Space Administration (NASA), the Secretary of the Army, the Secretary of Defense. Authority is normally conferred by explicit statutory provision: (I) for NASA, $\$ 203$ (b) (3) and (5) of the Space Act, 42 U.S.C. $\$ 2473$ (b) (3) and (5) authorize the Administration to make contracts for certain stated purposes and $\$ 202(a), 42$ U.S.C. $\$ 2472$ gives the Administrator responsibility for and authority over the powers, duties, activities, and personncl of NASA. (2) Io U.S.C. $\$ 3012(b)(1)$ gives the Secretary of the Army authority to conduct logistical support and research and development by the Army and Io U.S.C. $\$ 3012(d)(r)$ authorizes him to supervise the procurement activities of the Army. (3) However, ro U.S.C. $\$ 3012$ (b) also provides (as added by $\$ 2 \pi$ r, Pub. L. $87-65 I, 76$ Stat. 524 (I962)) that the Secretary of Army is responsible to the Sccretary of Defense for the operation and efficiency of the Army Department, and ro U.S.C. $\$ 30$ ro (as added by $\$ 210(a)$, Pub. L. 87-65I, 76 Stat. 524 (I962)) that the Army Department operates under the "authority, direction; and control" of the Secretary of Defense. By Io U.S.C. $\S$ I33 (as added by $\S 202$, Pub. L. $87-651,76$ Stat. $517(1962)$ ) the Secretary of Defense is given wide powers over the military departments (including the Army Department). Among such powers is broad authority to reorganize functions within the Defense Department (ro U.S.C. $\$ \$ 25-26$, as added by $\$ 201$ (a), Pub. L. $87-651,76$ Stat. 515-16 (I962)). Subject to the President's approval, the Secretary of Defense or his designce is authorized to engage in basic and applied research programs and conduct research and development projects by contract and otherwise. Io U.S.C. $\$ 2358$, as added by $\$ 208$ (a), Pub. L. 87.651 , 76 Stat. 523 (1962). An intricate set of provisions for the distribution of power, but in substance the Secretary of Defense is at the apex of the hierarchy of control. I should point out that both NASA and the Army Department conduct procurement under the Armed Services Procurement Act (ro U.S.C. $\$ \$ 2301-1_{4}$ as amended) pursuant to 1o U.S.C. $\$ 2303($ a), as amended. However, the National Aeronautics and Space Administration is not subject to the authority of the Secretary of Defensc.

${ }^{\circ}$ For functions of the Attorney General, see 5 U.S.C. $\$ \$ 303,304,306$, as amended, $\$ \$ 307,309,310$. These sections give the Attorney General wide responsibility and authority in giving legal advice and opinion to the President and the departments concerned as well as control (with the Solicitor General) of litigation in the Supreme Court and the Court of Claims, and the right to conduct litigation which United States attorneys are authorized to conduct in the United States courts.

- The Comptroller General has many impressive powers. Among them are: settlement and adjustment of claims where the United States is debtor or creditor, $3 \mathrm{I}$ U.S.C. $\$ 7 \mathrm{I}$; conclusive certification of the balances in the public accounts, $3 I$ U.S.C. $\$ 74$ (applying to the balances in the accounts of the executive branch which, of course, would include amounts available for contract expenditure); investigation and audit functions, $3 I$ U.S.C. $\$ \$ 53,65-67$; rendition of advance opinions on questions (in practice including legal questions) involving payments out of government funds, 3 I U.S.C. \$ 74. The reader should observe that Congress has classified the General Accounting Office as part of the Legislative Branch, 5 U.S.C. $\$ 133 Z-5$ ( $\$ 7$ of the Reorganization Act of 1949 , as amended and extended to June $I, 1963$ ).

'See, for example, the Assistant Secretary of Defense (Comptroller), ro U.S.C. $\$ 136$ (b) (as added by $\$ 202$, Pub. L. $87-65 \mathrm{r}, 76$ Stat. 518-19 (1962)); the Deputy Administrator of the National Aeronautics and Space Administration who "shall act for, and exercise the powers of, the Administrator during his absence or disability." $\$ 202$ (b), Space Act, 42 U.S.C. $\$ 2472(b)$.

${ }^{8}$ For an example, see NASA Management Manual 2-I-5 (June 12, I96I) setting forth the functions, 
classes of officers, I attempt an analysis of the key concept of authority to bind the United States on contracts: as generally understood, agents of the United States cannot bind it contractually except within the scope of their actual authority and concepts of apparent authority and estoppel are not for application. ${ }^{9}$ (4) Some treatment is given to procurement and contract regulations and their promulgation and effectiveness as well as to the impact of executive orders of the President. (5) A comparison is made between the availability of remedies against the United States and those available against private contractors. ${ }^{10}$

From this, the course proceeds into a consideration of a subject which lies at the core of consideration of government operations, including contracts: this is the subject of the laws and rules governing the use of appropriated funds. I must admit that judicial decisions are really not as important here as are decisions of the Comptroller General, who deals with questions of the legality of expenditures on a daily basis. Involved in the consideration are the constitutional provision on appropriations, ${ }^{11}$ statutory implementations of it, such as Revised Statutes $\S 3^{648}$ prohibiting the use of funds to make payments on contracts in advance of deliveries or performance of services unless otherwise authorized by law, ${ }^{12}$ and regulations pertinent to the whole scheme of control of appropriations. Consideration is also given to the functions of the Bureau of the Budget, the Comptroller General, disbursing and certifying officers of the government. I spend some time on the Appropriations Committees of the House and the Senate and, in addition, on the relation between authorization and appropriation acts. ${ }^{13}$

responsibility and authority of the General Counsel of NASA. The Office of General Counsel is not specifically provided for in the Space Act.

${ }^{\circ}$ The case usually cited is Federal Crop Insurance Corporation v. Merrill, 332 U.S. 380 (1947). See also Newman v. United States, I33 Ct. Cl. 429, I35 F. Supp. 953 (I955).

${ }^{20}$ Very generally: the United States as sovereign is entitled to immunity from suit by its contractors

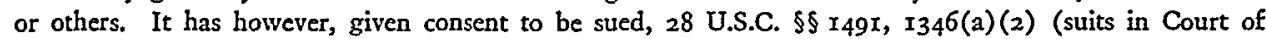
Claims and district courts on contracts, the latter courts being limited to claims not in excess of $\$ 10,000)$; but such consent must be strictly and conservatively construed, see United States v. Sherwood, 312 U.S. 584 (1941), and does not justify equitable remedies against the United States, United States v. Jones, I3I U.S. I ( 1889 ), although such remedies may be allowed as ancillary to a "legal" (i.e., damages) remedy, United States v. Millikin Imprinting Co., 202 U.S. I68 (I906). The United States is not encumbered as a litigant to the same degree: e.g., the statute of limitations and the doctrine of laches do not in general apply against it (but see Guaranty Trust Co. v. United States, 304 U.S. I26 (1938)); and it has certain preferential advantages: e.g., a contractor's right to counterclaim in a suit by the United States is limited, see 28 U.S.C. $\$ 2406$; United States v. Shaw, 309 U.S. 495 (I940); Whelan, A Government Contractor's Remedies: Claims and Counterclaims, 42 VA. L. REv. 301 (1956). The United States may sue in the district courts, 28 U.S.C. $\$$ I345, or in state courts. Cf. United States v. Bank of New York \& Trust Co., 296 U.S. 463 (1936).

${ }^{11}$ U.S. Const, art. I, $\S 9, \mathrm{cl} .7$.

${ }^{13}$ Rev. Stat. $\$ 3648$, as amended, 3I U.S.C. $\$ 529$ (I958).

${ }^{13}$ An authorization act is an act which authorizes appropriations to be made. Agencies subject to the authorization act requirement first present their budget plans for the fiscal year (after, of course, clearing them through the executive branch) to the congressional committees within whose legislative jurisdiction the affairs of the agency lie. After the authorization act is approved by the President, then it is in order for Congress to consider an appropriation act, that is an act appropriating money from the Treasury for the agency. Congressional committee action on the appropriation act is taken by the respective appropriation committees of House and Senate. For example, the National Aeronautics and Space Administration is required to submit its entire appropriation request to the authorization procedure by 
Following this the course enters into the truly complicated statutory and regulatory rules governing the making of contracts. Most people are acquainted with the general rule that the government makes its contracts by formal advertising; but I find it necessary to spend some time in explicating the highly technical nature of formally advertised contracts ${ }^{14}$ and the highly technical rules which permit government agencies to choose to "negotiate" instead of advertise their contracts. ${ }^{15}$

No analysis of the making of contracts would, of course, be complete without some attempt to point out the methods by which they are "priced"-that is, the methods by which the government may agree to reimburse the contractor. The government is not completely free in this area to make, without restriction, the choices available to private contractors in dealing with one another. Statutes and regulations control contract pricing as well as contract making. ${ }^{10}$ It might be well to point out here that one of the continuous threads running through government contract law and practice is the process of statutory and regulatory change. In the field of contract pricing, this is strikingly manifested by the recent Hebert Act, Public Law $87-653,{ }^{17}$ which creates some rather formidable devices to protect the government against over-pricing by contractors.

Related to both contract making and contract pricing is the subject of contract clauses, forms, and regulations. There are so many clauses, forms and regulations that in a two-hour course such as mine it is hopeless to engage in any exhaustive analysis. But I do try to emphasize the general aspects of two very prominent forms containing standard clauses, U.S. Standard Form $23 \mathrm{~A}^{18}$ and $32,{ }^{10}$ to discuss something of the development and promulgation of these forms (which is a study in inter-departmental operations), and give some general ideas about the way in which government procurement contract regulations are made and amended. I require my students to buy copies of the current version of title $4 \mathrm{r}$ of the Code of

73 Stat. 75 ( 1959 ). The NASA authorization bill comes before the Senate Committec on Acronautical and Space Sciences and the House Committee on Science and Astronautics. The latest NASA authorization act (titled "the National Aeronautics and Space Administration Authorization Act, I964") is Pub. L. 88-113, 77 Stat. $x_{4} 1$ ( 1963$)$. NASA appropriations are included in the annual Independent Offices Appropriation Act [for 1964 , see Pub. L. 88-215, 77 Stat. 425, 439-40 (1963)]. NASA appropriations come before subcommittees of the Senate and House Appropriations Committees. The reader might wish to note that the mere fact that a given amount is authorized to be appropriated does not not mean that such an amount will be appropriated. The authorization does serve as a ceiling but not as a floor; for example, compare the amount authorized for NASA in 1964 , supra, with the amount appropriated. The requirement that the entire appropriation request be submitted to the authorization procedurc is now also applicable to the AEC. Sec. I07, Pub. L. No. 88-72, 77 Stat. 88 (1963), 42 U.S.C.A. \$2017 (I964).

24 For an example of some of the rules, see Federal Procurement Regulations (FPR) 5 I-2, 4 I C.F.R. Part I-2 (I963).

${ }^{15}$ See Io U.S.C. $\$ 2304$ (a) (the Armed Services Procurement Act) as implemented in Armed Services Procurement Regulation (ASPR), sec. III, part. 2; $\$ 302$ (c) of the Federal Property and Administrative Services Act of 1949 , as amended, 4 I U.S.C. $\$ 252$ (c), as implemented in FPR $\$ \times-3.2,4 \times$ C.F.R. Subpart. I-3.2.

${ }^{10}$ For example, see Io U.S.C. $\$ 2306$; $\$ 304(\mathrm{~b})$, Federal Property and Administrative Services Act, as amended, 4 I U.S.C. $\$ 254$ (b).

${ }^{17} 76$ Stat. 528 (1962), amending various sections of the Armed Services Procurement Act, ro U.S.C. $\$ \$ 2301-I_{4}$ (Supp. I963).

${ }^{18}$ FPR $\S I-I 6.90 I-23 A$, 4I C.F.R. § I-I6.90I-23A (I963).

${ }^{10} \mathrm{FPR} \$ \mathrm{I}-16.901-32$, 4 I C.F.R. \$ I-I6.90I-32 (I963). 
Federal Regulations, which contains not only the standard forms but also the principal procurement regulations of the so-called "civilian" agencies of the governmentthat is, agencies outside the Department of Defense. The importance of the study of clauses, forms and regulations has recently been magnified by the decisions of the Court of Claims in the G. L. Christian case, about which I will have brief comment later in this paper. ${ }^{20}$ Quite relevant to a consideration of contract clauses is a study of the many statutory and regulatory policies which relate to contracts and contract performance and which are carried out through pertinent "clauseology." Examples abound: the Buy-American Act, ${ }^{21}$ the Covenant Against Contingent Fees, ${ }^{22}$ Examination of Records, ${ }^{23}$ and others. ${ }^{24}$ Among the more important features of such policies and their implementing clauses is their relation to the governmental process. The Examination of Records clause, for example, is not only of meaning for contractors and subcontractors. It is also a significant example of the way power and responsibility are distributed within the government: the statute and the implementing clause give to the General Accounting Office (GAO) the right to examine a contractor's books, records, and papers pertinent to the contract. ${ }^{25}$ Because of a "flow-down" requirement, the GAO will have the same right with respect to subcontractors. $^{26}$ Neither the statute nor the clause gives the same right to the agency which has made and which administers the contract. This must in some cases prove an interesting embarrassment, because GAO represents Congress in contract investigations, except in those cases where the agency has obtained for itself equivalent rights of examination. ${ }^{27}$

Following this, I take up several problem areas which, as I classify them, relate to contract administration (I would be the first to admit that they can be classified otherwise). These include the intricate problems of the impact of federal, state, and local taxation on government contracts, labor law aspects of government contracts, financial assistance by the government to its contractors and subcontractors, the general problem of the handling and disposal of government property (including property to which the government obtains title under the contract), and the relation-

${ }^{20}$ G. L. Christian \& Associates v. United States, 312 F.2d $4 \mathrm{I} 8$, motion for rehearing and reargument denied, 320 F.2d 345 ( I963) $_{3}$, cert. denied, 375 U.S. 954 ( 1963 ), rehearing denied, 376 U.S. 929 (1964).

${ }^{21} 47$ Stat. 1520 (1933), 4I U.S.C. \$\$ roa-Iod; implemented by Executive Order I0582 (1954), 3 C.F.R. r954 Supp.; by ASPR Sec. VI, parts $x$ and 2; FPR $\S$ I-6.2, 4 I C.F.R. Subpart I-6.2.

${ }^{22}$ See Armed Services Procurement Act, ro U.S.C. $\$ 2306(\mathrm{~b}) ; \S 304(\mathrm{a})$, Federal Property and Administrative Services Act of 1949, as amended, 4I U.S.C. $\$ 254(\mathrm{a})$; implemented in ASPR Sec. I, part 5 and FPR $\S \mathrm{x}-\mathrm{x} .5,4 \mathrm{x}$ C.F.R. Subpart $\mathrm{x}-\mathrm{x} .5$.

${ }^{33}$ See Armed Services Procurement Act, Io U.S.C. $\$ 23 I_{3}(b)$; $\$ 304(c)$, as amended, Federal Property and Administrative Services Act, $4 x$ U.S.C. $\$ 254$ (c); for the clause see ASPR $\S 7$-104.I5, FPR § I-7.Ior-IO, 4 I C.F.R. \$ I-7.IOI-IO.

${ }^{24}$ Readers interested in some of the other clauses which may be profitably discussed should see U.S. Standard Forms 23A and 32, cited supra, notes 18 and I9. There are a multitude of other clauses, e.g., see ASPR Sec. VII.

${ }^{25}$ Supra note 23.

${ }^{20}$ That is, prime contractors are required to include the clause in their subcontracts. See the clause, stlpra note 23 .

${ }^{27}$ Agencies do reserve more limited rights for examination of records, see, e.g., ASPR 8-70r(k); FPR $\$ \mathrm{I}-8.70 \mathrm{I}(\mathrm{k})$, 4I C.F.R. $\$ \mathrm{I}-8.70 \mathrm{I}(\mathrm{k})$. For reservation of rights to examine records in clauses issued under the Hebert Act, see the text, infra, at 342-43. 
ships between the government and subcontractors. In almost all of these areas, one can pick out very central issues relating to the distribution of power and responsibility within the government as well as important issues involving the government-contractor relationship. Although it is not an example which characterizes or summarizes the many areas of interest specified above, the nondiscrimination in employment policy (which I treat as a phase of the labor law aspects of government contracts) can be cited to illustrate some of the intra-governmental power problems arising in connection with contracts. This policy is not the creature of statute; instead it depends today on executive orders of the President. ${ }^{28}$ To effectuate the policy a contract clause obligating the contractor to observe certain rules as to nondiscrimination is required of contractors, and this clause contains a "How-down" provision thus extending its effectiveness to subcontractors. ${ }^{2 D}$ Executive departments and agencies are required to execute the policy by including the required provisions in contracts subject to the executive orders. ${ }^{30}$ Primary enforcement or "compliance" responsibility is vested in contracting agencies, ${ }^{31}$ but ultimate authority is vested in the President's Committee on Equal Employment Opportunity. ${ }^{32}$ The committee is given authority to issue regulation $\mathrm{s}^{33}$ and the contract clause requires compliance with them. ${ }^{34}$ In issuing its regulations the committee gave advance notice of its proposed rule-making, although public contracts matters are specifically exempted from the notice of proposed rule-making procedures requirements in section four of the Administrative Procedure Act. ${ }^{85}$ Aside from the vexing constitutional question of whether the President, without statute, has the authority to prescribe such a policy, ${ }^{36}$ other fascinating legal questions present themselves: how could the constitutional question be presented to the courts by a contractor or subcontractor who had (with supposed freedom of bargain) consented to inclusion of the clause in his contract or subcontract; to what extent would courts,

${ }^{28}$ Exec. Order No. 10925, 26 Fed. Reg. I977 (I96I), as amended by Exec. Order No. 11I14, 28 Fed. Reg. $6485-88$ ( 1963 ). Exec. Order No. IIII4 extends the policy to certain other programs involving federal assistance.

${ }^{20}$ An amended clause is prescribed by $\$ 201$, Exec. Order No. IIII4, supra note 28,28 Fed. Reg. $6486-87$ ( 1963 ). Subpara. ( 7 ) of this clause contains the "flow-down" provision, i.e., a provision requiring prime contractors to insert the clause (including subpara. (7)) in their subcontracts and purchase orders.

${ }^{30} \$ 301$, Exec. Order No. I0925, supra note 28 , as amended by $\$ 201$, Exec. Order No. 1III4, supra note 29,28 Fed. Reg. 6486 ( 1063 ).

${ }^{31} \$ 307$, Exec. Order No. rog25, supra note 28, 26 Fed. Reg. 1978 (rg6r).

22 See $\$ \$$ 306-15, Exec. Order No. I0925, supra note 28, 26 Fed. Reg. 1978-79 (196r).

${ }^{33}$ See $\$ 103,26$ Fed. Reg. I977 (196r), and $\$ 306,26$ Fed. Reg. 1978 (1961), of Exec. Order No. I0925, stipra note 28 .

${ }^{34}$ See subpara. (4) of the clause as amended, Exec. Order No. $\operatorname{xir} 4$, supra note 28, 28 Fed. Reg. $6487(1963)$.

${ }^{35}$ Sec. 4, Administrative Procedure Act, 5 U.S.C. $\$ 1003$ (1958).

${ }^{36}$ See Youngstown Sheet and Tube Co. v. Sawyer, 343 U.S. 579 (1952). In both Executive Orders Nos. I0925 and IxII4, supra note 28, the following statement of authority for the orders is madc: "NOW, THEREFORE, by virtue of the authority vested in me as President of the United States

by the Constitution and statutes of the United States, it is ordered as follows': 26 Fed. Reg. 1977 ( $196 \mathrm{r}$ ), 28 Fed. Reg. 6485 (1963). For comment on the constitutional problem, sec Pasley, The Nondiscrimination Clause in Government Contracts, 43 VA. L. Rev. 837 (1957). 
acting in chancery, undertake to supervise enforcement of the nondiscrimination contract provisions; is there any substantial issue involving the legality of expenditures of public funds on contracts containing the clause when Congress has not authorized the clause by express enactment? ? $^{37}$

After the discussion of the taxation, labor law, financial assistance, and property matters mentioned at the beginning of the previous paragraph, the course concerns itself with the two main forms of termination of contracts by the government: termination for default of the contractor under clauses inserted in contracts to allow the government to terminate for such causes ${ }^{38}$ and termination for the convenience of the government under clauses devised for that purpose. ${ }^{39}$ Unlike many other areas of government contracts, there are a large number of judicial ${ }^{40}$ and parajudicial decisions in this area. ${ }^{41}$ Nonetheless, some concerns of a purely public administrative nature remain. For example, the Comptroller General has never, to my knowledge, fully admitted the finality of settlements under the latter sort of termination. ${ }^{42}$ The Court of Claims has upheld finality of an administrative settlement in a similar case, but the effect of the decisions of that court as precedent

\footnotetext{
${ }^{37}$ Presumably the President (and the executive departments and agencies) has the authority to cncumber contract appropriations by such cost-producing requirements as records keeping, inspections and tests, and the like. Most of those requirements would seem to be related to the purpose of the contract as a device for acquiring property and keeping the cost down and the quality up. The question is whether he has the same authority to encumber when his objectives do not lie within the strict boundaries of contract performance but instead relate to social or general economic objectives. There is the question, of course, as to whether contract costs are actually increased by the nondiscrimination policy. The Comptroller General intimated that he had no evidence of any adverse effects or restrictions on competition in an opinion addressed to the Architect of the Capitol (a congressional official to whom, the Comptroller said, the President's nondiscrimination Executive Orders were not applicable by their own force). Ms. Comp. Gen. B-I 4547540 Comp. Gen. 592 (April 2I, I96I). In any event, although Congress during the post-war period circumscribed the availability of funds to the Fair Employment Practices Committce (National War Agencies Appropriation Act, 1946, 59 Stat. 473 (1945)), it has not prohibited the use of funds for the purposes of the President's Equal Employment Opportunity Committee despite long-continued knowledge of the Committee's existence. Cf. 2 JabEZ G. SUTHERLAND, Statutes and Statutory Construction $\$ 5107$ (Horack ed. 1953). Aside from a plausible legal fiction that continued legislative silence may imply acquiescence where knowledge is present, the sound conclusion seems to be that, at least to date, the balance of power in the Congress is such that neither express approval nor disapproval of the nondiscrimination policy can be articulated. Circumstances may well change, of course.

${ }^{38}$ See, for example, FPR $\$ \mathrm{x}-8.707,4 \mathrm{I}$ C.F.R. $\$ \mathrm{I}-8.707$ ( 1963 ); ASPR 8-707, 32 C.F.R. $\$ 8.807$ (I963) (for fixed-price supply contracts); FPR $\$ 8.709$, 4I C.F.R. \$ I-8.709 (I963); ASPR 8-709, 32 C.F.R. \$ 8.709 ( 1963 ) (for fixed-price construction contracts).

${ }^{30} \mathrm{Sec}$, for example, FPR I-8.70x, 4I C.F.R. I-8.7ox, ASPR 8-7or, 32 C.F.R. \$ 8.7or (Ig63) (for fixed-price supply contracts).

10 l.e., mostly from the Court of Claims, see 28 U.S.C. I $49 \mathrm{I}$, and the District Courts, see 28 U.S.C. $1346(a)(2)$.

"I have used the term previously to characterize the various boards of contract appeals, see Whelan \& Pearson, supra note I, at 326-3I. Jurisdiction of such boards is based on the standard "disputes" clause (sec, for an example, art. 12, U.S. Standard Form 32, FPR x-x6.901.32, 4I C.F.R. x-r6.901-32 (1963) and delegation of authority thereunder (for the Charter of the most active board, see ASPR, Appendix " $A$ " containing delegation of authority to the Armed Services Board of Contract Appeals).

${ }^{42}$ See, for example, the Comptroller's guarded statements in I8 Decs. CoMP. GEN. 826 (I939) and 29 id. 36 (1949). In testimony before Subcommittee 3 of the House Judiciary Committee in 1943, the then Comptroller General Warren seemed to admit the finality of administrative settlements. Hearings Before the Subcomm. No. 3 of the House Judiciary Comm. on H.R. 4789 and S. 1718 , 78th Cong., Ist Sess. rgr et seg. (1943).
} 
in the General Accounting Office has not always been optimum. ${ }^{43}$ Interest from the standpoint of public administration law in the subject of termination for convenience has received a recent fillip from the Court of Claims in G. L. Christian \& Associates $v$. United States, ${ }^{44}$ where the court held that a termination for convenience clause contained in regulations (which the court said had the force and effect of law) was imported into a contract even though the contractor had refused to accept it on the basis of consent and bargain. The case will be discussed somewhat more fully at a later point in this paper.

To the extent warranted by the current status of such legislation, the course next takes up the various forms of emergency legislation that have had an impact on contracts. Included have been such subjects as the Renegotiation Act (still of importance), ${ }^{45}$ emergency tax amortization, ${ }^{46}$ the Defense Production Act (parts of which are still in effect), ${ }^{47}$ title two, First War Powers Act, ${ }^{48}$ and others. Finally, the course takes up the remedial problems of government contracts. Always important and quite complicated, this subject deals with the jurisdictional position of the courts, ${ }^{49}$ the General Accounting Office, ${ }^{50}$ and the boards of contract appeals ${ }^{61}$ with respect to claims of contractors. It also includes some analysis of the claims and litigation posture of the United States. ${ }^{52}$

The preceding comments do not, of course, fully reflect the content of the course I teach, but I think they do reflect the fact that there are many areas of concern in the general subject of government contracts which are not reached by our traditional techniques of analysis which seem to be primarily analysis of judicial decisions or decisions resembling those of courts. My personal conviction is that we need to concern ourselves more with actions of the executive and legislative branches (including those cases of interaction between the two) than we do at present. I do not mean to suggest that courts are of minor importance; but I do suggest that we broaden our vision. For the purpose of illustrating some possible problems with which we might, as lawyers and law teachers, concern ourselves, I have included the following section of this paper.

${ }^{4}$ See Cannon Coastruction Co. v. United States, 3I9 F.2d I73 (Ct. Cl. 1963). Such authority as exists in the Supreme Court is on the side of the Court of Claims, Corliss Steam Engine Co. v. United States, 9I U.S. 321 (1875). For an early view of the Court of Claims from the Comptroller's chair, see 14 Decs. Comp. Gen. 648 (1935).

"See note 20 supra.

45 50 U.S.C. App. $\$ \$$ 12II-33 (termination date, June 30, 1964), 76 Stat. I34 (1962).

"10 INT. REv. CODE of 1954, \$ I68, not effective as to facilities which have not been certified as necessary by December 3r, 1959 .

${ }^{47} 50$ U.S.C. App. $\$ \$ 206 \mathrm{I}-66$ (effective in part until June $30,1964,76$ Stat. 112 (1962)).

18 Former 50 U.S.C. $\$ 6 \mathrm{II}$, as amended and extended and now superseded by 72 Stat. 972,50 U.S.C. $\$ \$ 43 I-35$.

${ }^{40}$ See note ro supra, for citations to some of the materials analyzed.

${ }^{50}$ See note 6 supra, for some relevant citations.

51 For a few relevant citations, see note $4 \mathrm{I}$ supra. Additionally, the course analyzes the finality of the Board of Contract. Appeals decisions under.the Wunderlich Act, 4I U.S.C. $\$ \$ 321-22$ (1963). For an important recent decision, see United States v. Carlo Bianchi, 373 U.S. 709 (xg63).

${ }^{2}$ See note ro supra. 


\section{Some Legislattve Problems}

I think that the foregoing emphasizes that the internal legal functions of government are a proper subject for concern of the lawyer and law teacher. The difficulty is, of course, the precise way in which we are to articulate what is "law" and what is "legal" in the context of the, so to speak, "interior" operations of the government. Our law school training and professional experience have emphasized the judicial to the extent that the judicial decision is to us largely-if not in some cases, exclusivelythe only intellectually satisfactory resolution of problems involving the law and legal relationships. And it is precisely in the area of interior government relationships, such as those which bulk of such large importance in government contracts, that judicial decisions are sparse and tangential. But it will not do to dismiss as "political science"-as some law professors and lawyers do, I am afraid-the study of a federal government of constitutionally limited powers such as ours, engaged as it is in the constant gestation of policy and other decisions all under the Constitution and statutes. Above all the content and quality of what is done, the nature of the decisions and their effects are, I think, a proper concern for the law, without its having any exclusive claim to the field. Professor John Mitchell once put it, we must cease our hypnotic fascination with procedure and try to provide a content for public law. ${ }^{53}$

A few brief examples of the possibilities-and the limitations, as well-of such study are pertinent at this point. I have chosen them from among some recent and relatively well-known happenings. Most of the information is available from public documents which makes these cases unusually useful in view of the fact that so often in studying interior government legal operations clear-cut documentary evidence of transactions is lacking.

\section{A. The RS-7o Case}

The heart of the issue here was whether, as a matter of strategic judgment, the country could be satisfied with its increasing armament of long-range missiles, or whether it needed, in addition, to have a supersonic bomber aircraft. This aircraft, known first as the B-7o and then the RS-yo, was under somewhat desultory development by the Defense Department. Representative Carl Vinson, Chairman of the House Armed Services Committee, felt that an increased pace was warranted. The Defense Department was obdurate in refusing to increase the pace and gave indications of abandonment of the project. As a result, in the bill authorizing missiles, naval vessels, and aircraft for the Department of Defense for $19633^{54}$ the House Committee, when it reported the bill out, ${ }^{55}$ included language directing the Secretary of the Air Force to spend a stated sum on RS-yo development. (Probably the major

${ }^{83}$ From the text of an obscure British journal.

os H.R. 975I, 87th Cong. (1962).

${ }^{65}$ H.R. Rep. No. 1406, 87th Cong., 2d Sess. (I962). 
portion of this sum would be spent through contracts.) At this point the issue developed from one of defense policy (on which both sides had taken a clear-cut stand) to one of legal right and constitutional power. Was it within the competence of the Congress to direct an officer of the executive branch to make expenditures and carry out a program? Undoubtedly in many cases Congress will have indirect means of persuasion or compulsion to effect its will in the executive branch, but in this case it had met stubborn refusal. Further, there had been refusals in the past to spend funds in connection with the composition or equipment of the armed forces although it had not been proposed to "direct" an executive officer in these cases, as far as I know. ${ }^{58}$ The House Committee felt that Congress possessed constitutional authority to issue such a direction because it was the constitutional duty of the Congress to "raise and support armies," to "provide and maintain a Navy," and to "make rules for the Government and Regulation of the land and naval forces." On the executive side, the feeling was, apparently, that the President was Commander-in-Chief under the Constitution and that, therefore, it was up to him to propose what the armed forces should consist of and up to Congress to grant or deny him what he proposed. ${ }^{58}$ As in so many cases, the Constitution itself could not be looked to for a black-and-white solution. The largest part of the Constitution-and this is often overlooked-is a charter for government operations, but it does not always delimit the boundaries of executive and legislative authority very clearly. In a case of this sort, where both sides were manned by strong men motivated by a sense of duty, how was resolution to be sought? In fact, resolution emerged from a talk between President Kennedy and Representative Vinson (termed by the newspapers, as I recall, the "walk in the rose garden") and Mr. Vinson agreed to a withdrawal of the word "directed" and substitution of "authorized" in the bill. ${ }^{59}$

Resolution could have been reached had the House and Senate enacted the bill with the word "direct" in it and the President had vetoed the bill. Or a different resolution could have been required if Congress enacted the language and the President accepted the bill while expressing the view that "direct" was unconstitutional and declining to give it literal application. A still different resolution would have been necessary had Congress re-passed the bill after a presidential veto. What led Mr. Vinson to change his mind and to withdraw "direct" from the bill I do not know, but clear it is that resolution was by negotiation (an over-quick cynic would say "by political pressure"). This does not, I think, excuse us from attempting to determine the constitutional right of the matter. Probably a court will never be

${ }^{56}$ See H.R. REP. No. I406, supra, at 5-6.

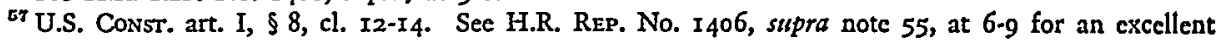
presentation of the Committee's views.

${ }^{88}$ U.S. CoNST. art. II, $\S 2$, cl. I contains the President's appointment as commander-in-chief.

${ }^{50}$ I08 Cong. Rec. 4335 (daily ed., March 21, 1962). There was an argument made at one point that "authorized" meant much more than "permitted" and, in fact, would be accepted by the Chief Executive as expressing congressional will and desire. I08 Conc. Rec. 4306-07 (daily ed., March 21, 1962). 
positioned to do so. Possibly no court has a right to do so when the controversy simply features differing legislative and executive interpretations of constitutional authority. But this is not to say that the legal profession cannot by its analysis, argument, and persuasion work out a solution which will be acceptable to Congress and the President on such a vital issue of the distribution of governmental powers. It would seem incumbent upon us to accept the challenge.

\section{B. "Sub-Congressional" Action}

It is common knowledge that the most significant part of Congress' activities are carried on in committee. The decisive act of voting takes place on the floor of House or Senate, of course, but investigation, informed discussion, and recommendation for legislation all come from committee. In fact, the action of committee may be decisive in determination of the question of whether Congress will legislate or how it will legislate. Members of committees tend to become expert in the matters regularly brought before their committees and it is important to observe that inasmuch as committees are given jurisdiction of the activities of executive departments or agencies, the expertise of the members of the committee will tend to narrow and focus on the business of the executive departments or agencies which they are called on to consider. If a department or agency regularly appears before a committee, it seems unquestionable that special relationships founded on skill, knowledge, and frequent contact will be formed. These factors may lead Congress formally to put in the hands of a committee the power, in effect, to represent Congress as in the case of the Joint Committee on Atomic Energy under section 164 of the Atomic Energy Act of $1954^{60}$ The committee was constituted by the act and, among its many other legislative duties, given the function of serving as a depository of certain electric utility contracts of the Atomic Energy Commission which should not become effective until thirty days (computed in the way prescribed by the act) after filing with the committee. This obviously does not say in so many words that the committee may disapprove such contracts or that it is the function of the committee to sit in judgment on them. But the committee is clearly in a position to do a great deal about contracts which it disapproves; its position of moral power and its ability to exercise political persuasion are obvious. The origin of this section appears to be connected with the famous Dixon-Yates controversy. There were then suspicions abroad that an Atomic Energy Commission contract for private electric power was going to be used adversely to Tennessee Valley Authority (TVA) and public power interests. ${ }^{61}$ But the speculation which must remain open is whether it is appropriate for committees of Congress to possess this degree of persuasive power. After all, contracts appear to be executive business and although Congress has laid down appropriate general criteria to govern the executive branch in making con-

${ }^{00} 68$ Stat. 951 (1954), 42 U.S.C. $\$ 2204$ (I958).

${ }^{01}$ See Aaron Wildavsky, Dixon-Yates if 126 (I962). See also H.R. Reps. Nos. 2639, 2666, 83d Cong., $2 d$ Sess. (1954), on the Atomic Energy Act of r954. Pertinent comments from these reports are reprinted at 1954 U.S. Code Cong. \& Adm. Service 3532, 3537. 
tracts, it might be argued that Congress is going too far in requiring that one of its committees be notified in advance before contracts become effective. It must be observed that Congress has not required committee approval before such contracts become effective. Presumably, such action would be subject to the objection that neither Congress nor a committee of Congress could thus intrude on executive functions. But such objections might well be regarded as failing if the requirement of notice to Congress or of committee approval were found in an act signed by the President.

The National Aeronautics and Space Administration (NASA) has been subjected to a considerable number of these congressional "checks," perhaps more than any other agency. ${ }^{62}$ Two examples, taken from the most recent appropriation for the Administration, will illustrate this. Money is made available to NASA in the annual Independent Offices Appropriation Act. ${ }^{63}$ As is frequently the case, Congress, in enacting this appropriation, places conditions and limitations on the funds available to an agency. There are limitations and conditions applicable to all the funds ${ }^{04}$ appropriated by the act and also conditions and limitations specifically applicable to individual agencies. ${ }^{65}$ In NASA's case, a series of paragraphs entitled "General Provisions" applicable to Ig64 appropriations contain the following which are illustrative of the basic problem suggested in the preceding discussion: ${ }^{06}$

No part of any appropriation made available to the National Aeronautics and Space Administration by this act for "Research and Development" may be used for the construction of any major facility, the estimated cost of which, including collateral equipment, exceeds $\$ 250,000$, unless (I) a period of thirty days has passed after the receipt by the Committee on Science and Astronautics of the House of Representatives and the Committee on Aeronautical and Space Sciences of the Senate of notice of the nature, location, and estimated cost of such facility, or (2) each such committee before the expiration of such period has transmitted to the Administrator written notice to the effect that such committee has no objection to the construction of such facility.

No part of any appropriation made available to the National Aeronautics and Space Administration by this act shall be used for expenses of participating in a manned lunar landing to be carried out jointly by the United States and any other country without consent of the Congress.

In the latter case, the objection based on the foreign affairs powers of the President seems clear: whatever may be the President's power to make "executive agreements"

\footnotetext{
${ }^{62}$ In addition to the matters discussed in the text, NASA under its required authorization and appropriation procedure presents its annual requests for money to four congressional committees. Sec note $\mathrm{r}_{3}$, supra.

${ }^{03}$ For the 1964 NASA Appropriation, see Pub. L. 88-215, the Independent Offices Appropriation Act for 1964, 77 Stat. $425,439-40$ (1963).

${ }^{8}$ General provisions of this sort applicable to all the funds under the act are found, for $\times 964$, at 77 Stat. $447-448$ ( 1963$)$. The Independent Offices Appropriation Act, I964, deals also with government corporations. General limitations and conditions applicable only to the "independent offices" (i.e., a wide range of federal executive agencies from the Executive Office of the President to the Veterans Administration) and not to the government corporations may be found at 77 Stat. $443-444$ (1963).

${ }^{86}$ For example, provisions applicable to the General Services Administration can be found at 77 Stat. 436-37 ( 1963$)$.

77 Stat. 439-40 (1963). (Emphasis added.)
} 
without Senate approval ${ }^{67}$ or his duty to submit "treaties" to the Senate for its advice and consent, ${ }^{68}$ the requirement that he submit a foreign undertaking for the approval of the whole Congress-which seems to be the only interpretation warranted hereis a seemingly novel approach to foreign relations for which foundation can be laid, if at all, only in the appropriation power. ${ }^{69}$ But it is the former provision which is more pertinent to the general theme of this paper and of the symposium of which it is a part, namely, a provision requiring that committees be notified of construction projects-which will, of course, ultimately involve contracts. One has the feeling that the provision trembles on the verge of giving to the committees the power of disapproval. Undoubtedly, committee expressions of disapproval will have some effect. It is worthy of note that this provision differs from the Atomic Energy Act provision referred to earlier, in that notice is required to be given to the Space Committees of proposed construction projects rather than of contracts. I believe that in the normal course of affairs the definition by NASA of needed construction and the determination that projects ought to be undertaken will precede by some time the making of contracts therefor, so that the committees will have the opportunity to exert their influence rather early in the game. Whatever may be done thereunder, the provision does nothing more than lay down a notice requirement and prescribe a period of pause lasting thirty days, or a shorter period if both committees approve in less than that time. In no express way has Congress attempted to supplant the executive, but whether in actuality it will attempt to do so by future amplifications of the provision remains to be seen.

An example may be found where Congress expressly conditioned the effectiveness of executive branch action, in this case by providing that proposed executive action should not be taken if disapproved by either the House or the Senate Appropriations Committees. The language used is somewhat reminiscent of the I949 Reorganization $\mathrm{Act}^{70}$ and the Department of Defense Reorganization Act of $1958 .^{71}$ Congress provided in the Department of Defense Appropriation Act, $1956:^{72}$

Section 638. No part of the funds appropriated in this Act may be used for the disposal or transfer by contract or otherwise of work that has been for a period of three years or more performed by civilian personnel of the Department of Defense unless

${ }^{07}$ See United States v. Belmont, 30I U.S. 324 (1937); United States v. Pink, 315 U.S. 203 (1942).

${ }^{08}$ U.S. Const. art. II, $\$ 2$, cl. 2.

${ }^{\circ}$ Id. art. I, $\$ 9$, cl. 7: "No money shall be drawn from the Treasury, but in consequence of appropriations made by law ...." The argument may be made that, while Congress cannot abridge the Chief Executive's power to make executive agreements-and a joint lunar landing program would presumably be in that category-it is certainly entitled to place restrictions on his expenditure of public funds. Clearly enough (without stepping outside the Constitution) the President cannot compel an appropriation, nor can he be legally compelled to approve one; and when he signs an appropriation containing what he feels to be illegal or unacceptable conditions on his powers, he may by his act of approval give a practical construction to the Constitution which is binding on him and on the executive branch.

${ }_{70} 5$ U.S.C. $\$ \$ 1332-15$, expired 1963,75 Stat. 4 I (196r).

72 53. Department of Defense Reorganization Act of 1958,72 Stat. 514, 514-16 (1958). This provision was repealed by 76 Stat. 526 ( 1962$)$ and the subject matter is covered by Io U.S.C. $\$ 125$, as added by $\$ 201$ (a), 76 Stat. 515-16 (1962).

${ }^{72} 69$ Stat. 321 (x955). (Emphasis added.) 
justified to the Appropriations Committees of the Senate and House of Representatives, at least ninety days in advance of such disposal or transfer, that its discontinuance is economically sound and the work is capable of performance by a contractor without danger to the national security: Provided, that no such disposal or transfer shall be made if disapproved by either committee within the ninety-day period by written notice to the Secretary of Defense.

The Attorney General advised the President that the proviso was unconstitutional. ${ }^{73}$ The proviso was not found in the Department of Defense Appropriation Act, 1957. ${ }^{74}$ A set of provisions resembling this one was enacted in $195{ }^{75}$ This required the three military service Secretaries and the Federal Civil Defense Administrator to "come into agreement with" the Senate and House Armed Services Committees in connection with certain real estate transactions, including leases or sales of government land. Presumably-although this is not expressly stated-the agreement was to precede the lease or disposal and to be a condition precedent on carrying out a lease or disposal action. Unlike the provision quoted above, this qualification on real estate transactions by the executive was not a condition in an appropriation act nor was it limited to an appropriation year, or any fixed period of time. It was intended as permanent legislation. It was included in the U.S. Code ${ }^{76}$ until repealed. ${ }^{77}$ At the present time the same subject is more explicitly covered by section 2662 of title Io, which states: ${ }^{78}$

"(a) The Secretary of a military department, or his designee, must come to an agreement with the Committees on Armed Services of the Senate and the House of Representatives before entering into ... [describing the real estate transactions covered]."

Of course, this sort of provision may have a special basis in the Constitution: ${ }^{70}$ "The Congress shall have power to dispose of and make all needful rules and regulations respecting the territory or other property belonging to the United States ...."

It can be argued that the approval requirements of section 2662 are simply delegations to congressional committees of congressional power. The act, of course, received presidential approval. Most of the rules and regulations governing the disposal of government property are found in title two of the Federal Property and Administrative Services Act of 1949 , as amended, ${ }^{80}$ and rules promulgated in pursu-

${ }^{73} 40$ Ops. Atr'y Gen. No. 32 (July 13, 1955). Bat cf. Jerry Maitico v. United States, 302 F.2d 880 (D.C. Cir. 1962).

74 70 Stat. $455-73$ (1956).

${ }^{75} 65$ Stat. 365-66 (195I).

76 Formerly 40 U.S.C. $\$ \$ 551-54$. Code.

${ }^{77}$ By $70 A$ Stat. 682 (1956), the act codifying the military laws into the present title 10, United States

${ }^{78}$ Emphasis added.

${ }^{79}$ U.S. Const. art. IV, $\$ 3$, cl. 2.

${ }^{80}$ For relevant provisions, see 40 U.S.C. $\$ \$ 48 \mathrm{r}-92$. 
ance thereto by the General Services Administration, and implemented by other agencies. ${ }^{81}$ Thus, Congress relies on the executive branch to carry out the task of disposal of property. But how can objection be raised if Congress chooses to place a restraint on the executive by requiring compliance with the approval requirements cited? Perhaps the only objection is a theoretical one: the Constitution gives Congress power of control and disposal of property, not a committee; Congress should, therefore, act in corporate fashion with the freedom of debate and the right to express himelf possessed by any member of either House in proceedings before that House. Certain advantages to the states may accrue from this. If federal land in South Dakota is sought to be disposed of and no member from South Dakota is on either of the committees, at least a Senator or Representative from the state could express his disapproval or approval and cast his vote on the floor. Undoubtedly, of course, the committees will be willing to hear him voice his views in their proceedings.

Another example of oblique exercise of the congressional power occurred in 1960-6I. After studying the contract pricing and related practices of the armed services pursuant to the Renegotiation Act amendments of $1959{ }^{82}$ the House of Representatives passed a bill which imposed numerous qualifications on contract pricing and contractor reimbursement. ${ }^{83}$ The Senate felt that there was merit in all the requirements of the House bill, but disagreed that the sought-after improvement of pricing needed to be achieved by statute. The Senate Committee stated its opinion $^{84}$ that the procurement regulations of the armed services could be amended so as to accomplish the same purposes. After this gentle exercise of the power to withhold legislation, the Armed Services did proceed to change their regulations ${ }^{85}$ in a way calculated to meet the sentiments of House and Senate. One finds it hard to categorize this sort of action; the President was not given the formal opportunity to participate that he is given when Congress legislates by bill, ${ }^{86}$ nor did the whole Senate (as distinguished from the committee involved) express its will. Ironically, while the Senate committee action quickly produced the desired changes in regulation by the Department of Defense, it did not produce satisfactory compliance either with those regulations or the sentiment of the House. In 1962, the House felt that

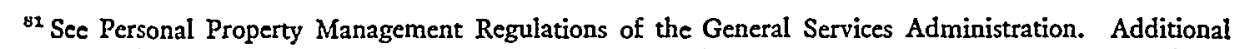
regulations of GSA are found in FPR $\S$ I-5.3, 4 I C.F.R. Subpart 1-5.3; FPR $\$$ I-8.5, 4 I C.F.R. Subpart r-8.5. For agency implementation, see ASPR Sec. VIII, part. 5 .

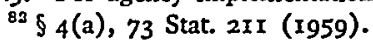

${ }^{83}$ H.R. 12572, 86th Cong. (1960). This bill was supported by H.R. ReP. No. 1797, 86th Cong., 2d Sess. (Ig60). The House Armed Services Committee study pursuant to the Renegotiation Act amendments, supra, was separately reported in H.R. REP. No. 1959, 86th Cong. 2d Sess. (1960). H.R. I2572 passed the House on June I3, I960, I06 CoNG. Rec. I4255-56 (r960).

84 S. REp. No. I900, 86th Cong., 2d Sess. 26-29 (1960). This report was not a report on H.R. 12572, but rather the report of the Senate Armed Services Committee pursuant to the requirements of $54(a)$, Renegotiation Act amendments, note 82 supra.

${ }^{B 5}$ See 107 Cong. Rec. I5 (daily ed., Feb. 2, I96r).

so The normal path for legislative action is passage of a bill by House and Senate and approval by the President or veto by him. Bills vetoed can, of course, be passed by Senate and House over the President's veto. This is all prescribed in U.S. ConsT. art. I, $\$ 7, \mathrm{cl} .2$. 
legislation was required and unanimously passed a bill similar to the one it had passed two years before. ${ }^{87}$ After several amendments the bill won acceptance in the Senate and approval by the President. ${ }^{88}$ This act, sometimes called the "Hebert" Act (after one of its more forceful sponsors in the House), was originally the cause of considerable consternation among contractors, subcontractors, and, indeed, some officers of the Defense Department.

Another example (though not one impinging directly on contract problems) of congressional concern over executive activities and anxiety to take action lies in the whole interesting relationship between the executive departments and agencies and congressional committees which desire to inform themselves about what the departments and agencies are actually doing. Most of the time the information is quickly made available, but often enough it is not. This has occurred sufficiently often for a subcommittee in the House ${ }^{89}$ to have exercised long-term surveillance over the availability of information including cases where the claim of "executive privilege" has been made. The hearings and reports of this subcommittee make fascinating reading; some of the reports are cited in the footnote. ${ }^{01}$ To my mind the most striking example of a congressional attempt to assert its right to information is told in a case involving the former International Cooperation Administration (ICA). ${ }^{02}$ ICA had refused to reveal certain information in its files to a congressional committee and in this refusal had been backed up by the Secretary of State. "Executive privilege" was invoked to sustain this refusal. This overlooked provisions in the Mutual Security $\mathrm{Act}^{93}$ and the Mutual Security Appropriation Act ${ }^{94}$ commanding the furn-

${ }^{87}$ H.R. 5532, 87th Cong. (196r). Although the bill was introduced in $196 \mathrm{x}$, it was not reported out until 1962 , H.R. No. 1638,87 th Cong., $2 d$ Sess. (1962). After some amendments on the floor of the House, it was unanimously passed, ro8 Cong. Rec. 9243 (daily ed., June 7, 1962).

${ }^{88}$ See S. REP. No. 1884,87 th Cong. $2 d$ Sess. $(1962)$. The House acecpted the Senate amendments, I08 Cong. Rec. I6852-52 (daily ed., August 28, I962). The bill was approved by the President, Pub. L. $87-653,76$ Stat. 528-29 (I962), Io U.S.C. $\$ 2304$ ef seq. (1963).

${ }^{80}$ The Special Government Information Subcommittee of the House Government Operations Committee, most often known as the "Moss Subcommittee" after its Chairman, Representative John E. Moss of California.

${ }^{80}$ It is enough for our purposes to describe this as the asserted right of the executive branch to kecp information or papers confidential in the public interest. It has had its judicial manifestations (sce Jencks v. United States, 353 U.S. 669 (I959); Touhy v. Ragen, 340 U.S.C. 462 (I95I); United States v. Reynolds, 354 U.S. I (1952); and cf. Duncan v. Cammell, Laird \& Co., [1942] A.C. 624 (H.L.). Jencks, of course, resulted in the "Jencks Statute," 7I Stat. 595 (1957), I8 U.S.C. $\$ 3500$ (1958), and in this statute Congress seemed to display a more indulgent attitude to the claim of executive privilege when made before the courts than it does on occasion when the privilege is exercised in legislative proceedings.

${ }^{91}$ H.R. REP. No. 157, 85th Cong., Ist Sess. (I957); H.R. Rep. No. 16r9, 85th Cong., 2d Sess. (1958) (Scientific Information and National Defense); H.R. REP. No. 1884, 85th Cong., 2d Sess. (1958) (Department of Defense); H.R. ReP. No. 234, 86th Cong., Ist Sess. (r959) (Air Force Refusal to the General Accounting Office); H.R. Rep. No. 2084, 86th Cong., 2d Sess. (r960) (The First Five Years and Progress of Study, August rg59-July 1960); H.R. REP. No. 1215, 87th Cong., 1st Sess. (196r) (Telephone Monitoring); H.R. REP. No. 1898, 87th Cong., 2d Sess. (1962) (Telephone MonitoringSecond Review). For some other reviews of the subject see Volume r9, Number r, Federal Bar Journal (I959), an entire issue devoted to "Executive Privilege: Public's Right to Know and Public Interest."

${ }^{2}$ Part VI, A Case Study of Executive Privilege, H.R. RË. No. 818, 87th Cong., Ist Sess. I55-94 (I96r).

${ }^{93}$ Former 22 U.S.C. $\$$ I793a(d), repealed 75 Stat. 460 (r96r).

91 $\$$ IoI(d) of the Mutual Security and Related Agencies Appropriation Act, r961, 74 Stat. 776. 
ishing of the sort of information Congress desired. The Comptroller General, acting under his interpretation of the provisions involved, ordered that appropriated funds be withheld if the requested documents were not submitted. ${ }^{95}$ The Attorney General advised the President that the position taken by the Comptroller General was in his opinion not supported by the statutes involved and that, if the statutes should be regarded as supporting the Comptroller, then their operation here was unconstitutional because violating the separation of governmental powers prescribed by the Constitution. ${ }^{98}$ Whether the money involved was actually spent by the State Department, I do not know; but the controversy over the documents was ultimately resolved by the Kennedy Administration when it withdrew the claim of executive privilege and allowed the Subcommittee of the House Government Operations Committee to have the papers. ${ }^{97}$ Despite the resolution of the controversy in this fashion, a rider has been included in the foreign aid appropriations acts for several years which authorizes cutting off the availability of funds if certain information has been denied. The following is an example of this provision: ${ }^{08}$

Section 602. None of the funds herein appropriated shall be used for expenses of the Inspector General, Foreign Assistance, after the expiration of the thirty-five day period which begins on the date the General Accounting Office or any Committee of the Congress, or any duly authorized subcommittee thereof, charged with considering foreign assistance legislation, appropriations or expenditures, has delivered to the office of the Inspector General, Foreign Assistance, a written request that it be furnished - document, paper, communication, audit, review, finding, recommendation, report, or other material in the custody or control of the Inspector General, Foreign Assistance, relating to any review, inspection, or audit arranged for, directed, or conducted by him, unless and until there has been furnished to the General Accounting Office or to such committee or subcommittee, as the case may be, (A) the document, paper, communication, audit, review, finding, recommendation, report, or other material so requested or (B) a certification by the President, personally, that he has forbidden the furnishing thereof pursuant to such request and his reason for so doing.

\section{Some Examples of Legal Problems in the Executive Branch}

The preceding set of examples have, in the main, dealt with some of the important relationships between the legislative and executive branches of the national

${ }^{\circ E}$ Ms. Comp. Gen., B-143777, Dec. 8, I960, reprinted in H.R. ReP. No. 8I8, 87th Cong., Ist Sess. r6r $-67(196 r)$.

${ }^{\circ}$ See Opinion of the Attorney General, Dec. I9, I960, reproduced in H.R. ReP. No. 8I8, note 95 supra, at 169-93. See also the letter of Attorney General Rogers to the President, dated Dec. 22, I960, id. at 194 .

${ }^{\circ 7}$ Sec H.R. REP. No. 818, note 95, supra at 155 .

${ }^{88}$ The quotation above is from $\$ 602$ of the Foreign Aid and Related Agencies Appropriation Act, 1964, 77 Stat. 857 ( 1964$)$. Predecessor provisions with substantially the same import may be found in: (a) $\$ 602$ of the Foreign Aid and Related Agencies Appropriation Act, 1963, 76 Stat. II 63 , II70 (1962); (b) $\$ 602$ of the Foreign Assistance and Related Agencies Appropriation Act, 1962, 75 Stat. 717,721 (196I); (c) $\S$ IOI(d) of the Mutual Security and Related Agencies Appropriation Act, 1961, 74 Stat. 776,778 ( 1960$)$; (e) $\$ \mathrm{III}(\mathrm{d})$ of the Mutual Security Appropriation Act, I960, 73 Stat. 7I7, 720 (1959). 
government. Almost all of the examples have [if one stops to think about it] cast some light on the actual constitution and operation of each of those branches. The executive itself furnishes some interesting problems. Some, but not all, of these are what I have previously indicated to be "in house" or "interior" legal problems of the government and part of the "law of public administration." Because it may be helpful to narrow the field and make some of my comments more concrete, the discussion which follows will use National Aeronautics and Space Administration statutes and regulations as media for illustrating some problems of interest which have arisen in other parts of the executive branch.

It may be of interest to readers to point out that the National Aeronautics and Space Administration is not what is generally called a "department," although it is clearly one of the so-called executive "departments and agencies" which form the principal corpus of the executive branch. It is not one of the so-called "regulatory agencies" so familiar to students of Administrative Law (i.e., the Federal Trade Commission, the Interstate Commerce Commission, and so on).

\section{Delegation of Authority Within an Agency: Internal Regulations.}

NASA's principal mission is to carry out the civilian aspects of the United States' space venture. ${ }^{100}$ Quite obviously this mission entails a fairly large staff, numerous and expensive contracts, and elaborate facilities. But NASA is not, as its principal task, engaged in issuing regulations for the public or in the function of implementing and carrying out laws which govern the economic affairs of the citizen. In this respect, it differs from the Federal Trade Commission and the other regulatory agencies which do carry out the function of executing laws directly applicable to the public. NASA's chief relationship with the public and with the national economy is through its contract and grant programs by which sectors of the nation (including individuals, private profit-oriented corporations, and non-profit organizations like colleges and universities) are mobilized to assist NASA in carrying out its mission. Quite obviously the NASA Administrator cannot make all the decisions which are involved in such an enterprise personally; he must authorize other officers and employees of NASA to make them. He is not going to make such an authorization (which obviously will have to go far down through the hierarchy below him) on a basis of carte blanche trust. Instead, he will control the exercise of delegated authority by rules and regulations which express not only authorization but re-

"Do "Department" is a term often used loosely to indicate an agency whose head is a member of the President's cabinet, although the term is applied technically in legislative usage to describe one of the major components of the executive branch. It would seem clear that Congress cannot prescribe membership in the cabinet and that it does not do so. In another connection "Department" may have a vital significance, namely, in fixing the salaries of heads of executive departments who are in the President's cabinet. 5 U.S.C. \$3. Not all heads of "departments" are cabinet members-e.g., the Secretary of the Army.

${ }^{100}$ See $\$ 102(b)$, National Aeronautics and Space Act of 1958, 42 U.S.C. $\$ 2451(b)$; $\$ 203$, Space Act, 42 U.S.C. $\$ 2473$. The National Aeronautics and Space Administration also took over the functions, powers, duties, and obligations of the former National Advisory Committee for Aeronautics, $\{30 \times(a)$, Space Act, 72 Stat. 432 (1958). 
striction. The Space $\mathrm{Act}^{101}$ authorizes the Space Administration ${ }^{102}$ "to make, promulgate, issue, rescind, and amend rules and regulations governing the manner of its operations and the exercise of the powers vested in it by law." NASA issues its regulations and operating instructions in a "Management Manual" and certain other internal administrative publications. ${ }^{103}$ A portion of the manual, chapter eighteen, ${ }^{104}$ deals with contracts matters and, in this respect, implements the Armed Services Procurement Act ${ }^{105}$ under which NASA makes contracts for procurement and construction. ${ }^{108}$ Parts of chapter eighteen include clauses which are required to be inserted in contracts made by NASA. ${ }^{107}$ Other portions of the Management Manual pertain to contracts in an indirect, but nonetheless relevant way, e.g., Management Manual 2-I-I.3A establishes the functions and authority of the Office of Procurement in NASA Headquarters and assigns to it the responsibility to "review, coordinate and approve" contracts and certain other transactions which require Headquarters approval. ${ }^{108}$ NASA issues other regulations governing such subjects as personnel and employment, ${ }^{109}$ security, ${ }^{110}$ reports, ${ }^{111}$ international programs, ${ }^{112}$ and still others too numerous to mention. Many, if not most, of these regulations, are what is called in the Administrative Procedure Act matters "relating solely to the internal management" of NASA. ${ }^{113}$ As such, they are probably exempt from publication in the Federal Register and the Code of Federal Regulations.114 Certainly, NASA regulations on the subject of government contracts are exempt from the "notice of proposed rule-making" provisions of section four, Administrative Procedure Act, as all government regulations on that subject appear to be. ${ }^{115}$ As

${ }^{101}$ Hereafter, the National Aeronautics and Space Act of 1958, 72 Stat. 426-38 (1958), as amended, will be called the "Space Act." Principal sections of the Space Act are found in 42 U.S.C. \$\$245I-76.

$102 \S 203$ (b) (I), Space Act, 42 U.S.C. $\$ 2473$. The Administrator of the National Acronautics and Space Administration, of course, exercises this power, $\$ 202(a)$, Space Act, 42 U.S.C. $\$ 2472(a)$.

${ }^{103}$ The complete Management Manual and NASA Circulars, Instructions, and Handbooks are not available in the Code of Federal Regulations. Portions of them may be found in $\mathrm{I}_{4}$ C.F.R. chapter V, and $4 \mathrm{I}$ C.F.R. chapter 18.

${ }^{104}$ Chapter 18 is usually referred to as "NASA PR" (NASA Procurement Regulations). Portions of it are contained in $4 \mathrm{r}$ C.F.R. chapter 18 . A revised edition of NASA PR was distributed in April 1964. This article refers to NASA PR as it existed prior to the revision, and to the Jan. I943 edition of N.I.C.F.R.

${ }^{106}$ 10 U.S.C. $\$ \$ 2301-14$, as amended.

${ }^{100}$ By $\$ 301$ (b), Space Act, 72 Stat. 432 (1958), Io U.S.C. $\$ 2302$ was amended so as to bring NASA within the provisions of the Armed Services Procurement Act.

${ }^{207}$ NASA PR Part 7 is the chief repository for contract clauses although clauses are found in many parts of the regulations. NASA PR Part 7 is contained in 4I C.F.R. Part r8-7. The seventh major subdivision of procurement regulations seems to be the place where the majority of contract clauses are placed: e.g., ASPR sec. VII, FPR I-7, 4 I C.F.R. Part I-7.

${ }^{108}$ NASA Management Manual 2-I-I.3A (effective July I, I963, per NASA Transmittal Sheet No. 645).

${ }_{100}$ E.g., NASA Management Manual chapter 3, parts I and 7, chapter I7.

${ }^{110}$ E.g., NASA Management Manual chapter 3, part. 4.

111 E.g., NASA Management Manual, chapter 6, part. 2.

112 NASA Management Manual, Chapter 13.

${ }^{118} \S_{3}$, Administrative Procedure Act, 5 U.S.C. $\$$ rooz (1958).

11 Ibid.; see also 44 U.S.C. $\$ 3$ II for the Federal Register Act.

${ }^{118} 5$ U.S.C. $\$ 1003$. 
in the case of other procurement regulations, NASA procurement regulations appear in the Federal Register and the Code of Federal Regulations. ${ }^{116}$

I do not mean to indicate that NASA is different in these respects from the rest of the departments and agencies. In all probability, the greater part of the regulations of the executive departments and agencies are not published in the Federal Register and the Code of Federal Regulations. Should they be required to be there published, the deluge of paper would probably be unimaginable. However, I should clearly state what I believe is the general experience of people in Washington: most agenciescertainly NASA-will in most cases make available to an inquirer a copy of agency regulations for retention or will permit the inquirer to examine at the agency's office a copy of such regulations. Probably, there are some regulations not so treated, but on the whole the departments and agencies are open in this respect. Certainly, this is in accord with the spirit of section three of the Administrative Procedure Act.117 At the time this is written, however, some members of Congress seek to obtain a greater openness, and legislation to achieve that aim has been introduced. ${ }^{118}$

But despite this, a problem remains: whether in a government which belongs to the people we can safely afford so much privacy in governmental organization? The problem of "executive privilege" to conceal information from Congress has been mentioned earlier; the problem here is different in its nature. It involves not so much the problem of restraint on the utterance of information as it does how to make information more widely available. Where, for example, is knowledge about the scope of authority of contracting officers of the government easily available? Such information is material if one accepts the thesis propounded in Federal Crop Insurance Corporation v. Merrill, ${ }^{119}$ that a contractor takes the risk that the government agent he deals with acts within the scope of his actual authority and that no apparent authority or estoppel principles are for application against the government. But lack of publicity about contract authority is only part of the problem, a sharply practical part, it is true. It seems to me that one ought to recognize that delegation of authority is an essential part of the conduct of public business and that delegations and the regulations mentioned above simply form part of a large corpus of "Public Administration Law." The generation, interpretation, application, and enforcement of these regulations and delegations is a proper matter for concern of the lawyer and law teacher not so much because the course of litigation may be determined thereby but because the internal regulatory process is a highly significant manifestation of the continuing vigorous evolution and unfolding of our constitutonal government.

${ }^{110}$ For NASA PR see 4 I C.F.R. Chapter r8.

${ }^{117} 5$ U.S.C. $\$ 1002$.

${ }^{118}$ See S. 1666, 88th Cong., introduced by Senator Long of Missouri, on June 4, 1963, 109 Cono. REc. 9393-95 (daily ed., June 4, 1963). This bill would amend $\S 3$, Administrative Procedure Act, 5 U.S.C. 1002 so as to provide for increased publicization of agency activities.

110 See note 9 supra. 
2. Procurement Regulations and Clauses: the Implications of Christian.

I have pointed out above that the NASA Administrator is equipped by the NASA Act with the authority to issue regulations for the governance of his agency. Similar authorizations are given to other government departments and agencies. Perhaps most noted among such authorizations is the so-called "house-keeping" statute:120

The head of each department is authorized to prescribe regulations, not inconsistent with law, for the government of his department, the conduct of its officers and clerks, the distribution and performance of its business, and the custody, use and preservation of the records, papers and property pertaining to it. This section does not authorize withholding information from the public or limiting the availability of records to the public.

The Secretary of Defense has separate authority to issue procurement regulations: ${ }^{121}$

Notwithstanding any other provision of law, an officer or agency of the Department of Defense may obligate funds for procuring, producing, warehousing or distributing supplies, or for related functions of supply management, only under regulations prescribed by the Secretary of Defense. The purpose of this section is to achieve the efficient, economical, and practical operation of an integrated supply system to meet the needs of the military departments without duplicate or overlapping operations or functions.

It is unusual in my experience that such a short section should make the legislative purpose so clear.

A question which, I think, rises naturally in most people's minds is the extent to which regulations dealing with contracts, issued under authorities like those above, become binding on contractors. In most cases, it would appear that the authors of procurement regulations did not intend that their regulations would bind persons other than the officers and employees of their own departments or agencies. In very few cases, however, is there really clear and complete evidence of what regulations-drafters intended, other than the text of the regulations themselves, because no "legislative histories" are made available to the public. ${ }^{122}$ Nor are procurement regulations, as mentioned earlier, subject to the "notice of proposed rule-making" provisions of section four of the Administrative Procedure Act. ${ }^{123}$

${ }^{130}$ REv. STAT. $\$$ I6I (I875), as amended by 72 Stat. 547 (I958), 5 U.S.C. $\$ 22$. Presumably, since Congress made this provision applicable to departments, it does not technically apply to an "administration" such as NASA.

121 Io U.S.C. $\$ 2202$.

${ }^{123}$ It should be noted that the regulations are kept up to date by means of periodic issuance of revised pages which reflect changes in, or additions to, the regulations. Normally these revised pages are accompanied by a page or pages listing and explaining the principal changes in the revised pages. E.g., NASA PR is changed by the issuance of revised pages under the cover of a "Transmittal Sheet" which will explain some of the major changes effected. The Armed Services Procurement Regulation is changed by means of "revisions" consisting of revised or additional pages covered by "Notes" explaining changes. None of these, although they are helpful, are usually enough to satisfy searching curiosity. The materials promulgated in ASPR are the product of the ASPR Committee which functions as an administrative "Iegislature" or "para-legislature" (see Whelan \& Pearson, supra note I, at 326-3I). Summaries of ASPR Committee activities are contained in "Minutes" which, I understand, are not available for general distribution.

${ }^{203} 5$ U.S.C. $\$ 1003$. 
Recent opinions of the Court of Claims, however, have spoken in this area. ${ }^{124}$ The court's two opinions in the Christian case make it clear that the court is willing to impose on a contractor the terms of a clause which was required by regulations although the contractor had refused to accept the clause as a matter of bargain. Without going into the merits of the Christian case (a subject which I am sure has been dwelt upon elsewhere in this symposium), ${ }^{125}$ it will be sufficient for our purposes here to point out one branch of the arguments used by the court to support its conclusion that clauses required by regulations could be incorporated into contracts by operation of law, namely, that if the regulations requiring the clause were authorized by statutes like the "housekeeping" statute and the act pertaining to procurement regulation by the Secretary of Defense, then such regulations have the "force and effect of law." The consequence of this is that the contract must be regarded as containing the clause. Such logical magic has been referred to by one of my students as a Procrustean bed, ${ }^{126}$ but, unfortunately Theseus did not see fit on this occasion to deal with Procrustes. ${ }^{127}$ There are undoubtedly other reasons for the Christian decision, but the use of the line of argument summarily stated above seems to indicate some thought-provoking possibilities. The Supreme Court gave the Court of Claims some support, it ought to be remarked, for the Court of Claims second opinion in Christian but not, apparently, for its first opinion. ${ }^{128}$ Two days after the first Christian opinion, the Supreme Court rendered its opinion in Paul v. United States ${ }^{129}$ which accorded the Armed Services Procurement Regulation the "force of law."130 But the Paul decision was speaking about portions of the Armed Services Procurement Regulation which implement specific provisions of the Armed

${ }^{124}$ G. L. Christian \& Associates v. United States, 312 F.2d 418 (Cir. 1963), motion for reliearing and reargument denied, 320 F.2d 345 (1963), cert. denied, 375 U.S. 954 (1963); J. W. Bateson Company, Inc. v. United States, 308 F.2d 510 (5th Cir. 1963). Petition for rehearing in the Christian case was denied, 376 U.S. $929(1964)$.

${ }^{125}$ See Donnelly, The Milkman Rings Twice: Has Paul v. United States Given Federal Procurement Regulations the Force of Statutory Law, this symposium, 347 at 353 . See also 51 GEO. L.J. 842 (1963); Cibinic, Contract by Regulation, 32 Geo. Wash. L. Rev. IxI (1963).

${ }^{120}$ David Delker, in a paper submitted in my Government Contract I course, Fall Term, 1963, and entitled "G.L. Christian-A Procrustean Bed."

${ }^{127}$ That is, the Supreme Court denied certiorari; see stupra note 124.

${ }^{128}$ One of the more forceful underlying reasons (not made much of by the Court) is the strong probability that the contractor in fact knew of the existence of the regulation requiring the "Termination for Convenience" clause. Another factor: in several places the contract made reference to provisions for termination, although, as was mentioned, the clause allowing termination for the convenience of the government was not included.

${ }_{120} 371$ U.S. 245 (1963). The Paul opinion is dated Jan. 14, 1963, two days after the first Christian opinion, 312 F.2d 418 ( 1963$)$.

${ }^{130}$ Patul relied in part on Public Utilities Comm'n of California v. United States, 355 U.S. 534 (1958), which like Paul involved collision between the pricing policy expressed in federal statute and implemented in federal regulations, on the one hand, and the rules of a state on the other. The state rulcs had to recede, of course, and the Public Utilities Comm'n opinion referred to the Armed Services Procurement Regulation (ASPR) as having the "force of law." Two cases were relied upon for this proposition, Leslie Miller, Inc. v. Arkansas, 352 U.S. I87 (I956), and Standard Oil Co. v. Johnson, 316 U.S. 48x (1942). It seems questionable that the Miller case has a clear holding on the point. Johnson recognized the immunity from state and local taxes of War Department post exchanges which were created under War Department Regulations. 
Services Procurement Act commanding price competition and the Court was faced with the question of whether the federal statute and the regulation implementing it would prevail over conflicting state rules. In holding that the federal statute and regulation prevailed, the Court used the "force of law" characterization, but it should be pointed out that the Court dealt with only a part of the Regulation and further a part which was firmly bedded on statutory policy. The Court came nowhere near saying that all of ASPR had such effect.

Some possibilities leap to mind: ( $I$ ) to what extent has the bargain element in government contracts been unduly depreciated-that is, are contractors deprived of their expectations when clauses to which they did not agree are found to apply to their contracts long after the time of making and probably after performance has been concluded? It does not seem to me to be enough to say, as might have been said in Christian, that the contractor knows or should know ${ }^{131}$ of the existence of the regulatory requirement that a clause be used. He should be able to rely on his bargain as made. (2) One possibility latent in the Christian approach is the application of the required clause doctrine to subcontractors. Clearly enough, many regulations require clauses to be incorporated by prime contractors in their subcontracts. ${ }^{132}$ Many of these are based on an underlying statutory provision, it is true, ${ }^{133}$ but some are not; ${ }^{134}$ but in either case if the prime does not include the required clause in the subcontract, is it bound to be regarded as incorporated therein nonetheless ? $^{135}$ (3) If a contract is to be deemed to include such required clauses, what status is to be given to post-contract modifications of a clause?' Procurement regulations are frequently modified. Whatever answers can be given to these questions, it is clear that Christian does not give them although the court did recognize the last-mentioned problem but eschewed dealing with it. ${ }^{136}$

${ }^{101}$ That is, to the extent published in the Federal Register and the Code of Federal Regulations. E.g., NASA PR, 4 I C.F.R. chap. I8. \$3, Administrative Procedure Act, 5 U.S.C: $\S$ Io02, can be construed to require publication of such regulations and publication in the Federal Register can be said to effect legal "notice," $\$ \S 5$, 7, Federal Register Act, 44 U.S.C. $\$ \$ 305,307$.

${ }^{123}$ E.g., see NASA PR 7.203.7(a)(a)(6) (Sept. I962), 4I C.F.R. \$ I8-7.203-6, a "Records" provision requiring prime contractors having cost-reimbursement contracts to include the provisions of the "Records" clause in certain of their subcontracts.

${ }^{133}$ For example, the "Examination of Records" clause, see note 23 supra. The NASA "Records" clause referred to in the preceding note in part reflects the "Examination of Records" requirement; see NASA PR 7.203-7(a) (a) (3), (6), 4 r C.F.R. $\$ 18-7.203-6$.

${ }_{134} A s$, for example, in the case of the nondiscrimination clause, see note 29 , supra.

${ }^{230}$ The better argument would seem to be that the contract should be read as written, i.e., without the clause. Yet the G. L. Christian case discussed in the text, supra at $33^{6}$, poses a difficult question. If the clause is to be read into prime contracts by operation of law, why should it not also be read into subcontracts? In American Pipe \& Steel Corporation v. Firestone Tire \& Rubber Company, 292 F.2d 640 (9th Cir. I96r), the court indicated that "federal" law should uniformly apply to primes and subs at least where their rights were referable to a standard federal contract clause. If this be so, it is a tenuous but not impossible inference that subcontractors may be liable to have required clauses read into their subcontracts even though the prime did not comply with the obligation he assumed to the government (as in the nondiscrimination clause, supra notes 29, 134). I know of no authority for this conclusion. The conclusion is a stronger one, it seems to $\mathrm{me}$, in cases where prime and subcontract clauses are required by statute as in the case of the "Examination of Records" provision, supra notes 23 and I33.

${ }^{180}$ See 320 F.2d 345,350 n.7. 
Suffice it to say that there are basic questions left unanswered. To say that "regulations have the force and effect of law" is, in my opinion, to ask the question rather than to answer it.

But the most striking question of all is neither articulated nor hinted at in the Christian decision. This question poses an underlying problem, possibly one not suitable for judicial disposition. The question is, just what should be the relationship of regulations of the executive branch to the citizen? I am not speaking now of regulations such as those mentioned earlier, issued by independent regulatory agencies whose mission is to regulate economic or other affairs of the citizen. Nor am I speaking only of regulations dealing with contract matters. There are over two million employees of the executive branch ${ }^{137}$ outside of the regulatory agencies; the regulations relating to them and their official functions number almost beyond imagination. The President can hardly supervise their issuance, let alone become familiar with their contents. Congress, or at least some congressmen, may be aware of their proliferating number. Can, or should, any control be imposed? The Christian decision makes an appealing case for some controls over contract regulations because of the practical immediacy of its implications for those businessmen who deal with the government, but the idealism of the Constitution seems to call for a citizenry equipped with knowledge of what its government is doing in all spheres, not only contracts. Quite frankly the basic policy issue seems to involve a practical dilemma: whether to impose some form of presidential or congressional control over the issuance of regulations, assuming that congressional control could be constitutionally imposed (which is not clear), or to permit continuance of the present system in which knowledge of regulations is far beyond most citizens and involves a priesthood of the arcane where one needs to be a specialist in the activities of one department, or perhaps of one bureau within a department, in order to be truly well informed. The former course would involve cumbersome and complicated procedures, the latter is more or less efficient but has its undesirable aspects.

To draw on our original example, we may pose the question: what is the binding quality of a regulation issued by NASA under the authority of section 203(b)(I) of the Space Act? ${ }^{138}$ Let us assume that our hypothetical regulation requires the insertion in certain contracts of the clause entitled "Termination for the Convenience of the Government."139 Does such a requirement have any effectiveness outside of NASA and does it bind persons other than NASA officers and employees? Is such a clause to be regarded as part of those NASA contracts which are subject to the regulatory requirement whether or not the contractor has con-

\footnotetext{
${ }^{137}$ See Staff of Senate Government Operations Comm., 88th Cong., 2ND Sess., Organization op Federal Executive Departments and Agencies, Committee Report No. 23, at 75-76 (Comm. Print I964).

${ }_{138} 42$ U.S.C. $\$ 2473(b)(-1)$.

${ }^{120} \mathrm{~A}$ requirement of this nature applicable to fixed-price supply contracts is found in NASA PR 8.70r.
} 
sented? Clearly this is the question answered affirmatively by the Christian decision. I would like to suggest a different analysis.

NASA Procurement Regulation I.IOI $^{\mathbf{1 4 0}}$ recites that the regulation is issued to establish uniform policies and procedures for procurement of property and services under the authority of the Space Act and the Armed Services Procurement Act. ${ }^{141}$ NASA Procurement Regulation I.I02 provides that the regulation applies to all NASA purchases and contracts, in or out of the United States, for the procurement of property or services "which obligate appropriated funds." upon an examination of the NASA Procurement Regulation, or the Armed Services Procurement Regulation, or the Federal Procurement Regulation, that none of these regulations are confined to a direct implementation of the substantive provisions of acts governing procurement procedure such as the Armed Services Procurement Act. Other statutory provisions are implemented in the regulations-e.g., the Walsh-Healey Public Contracts Act dealing with the conditions of labor under government supply contracts. ${ }^{143}$ It ought to be pointed out here that principal regulatory responsibility under the Walsh-Healey Act is given to the Secretary of Labor and that NASA procurement regulations direct compliance by NASA personnel with the Secretary's regulations and instructions. ${ }^{144}$ In addition, procurement regulations carry out policies of the Chief Executive, including the nondiscrimination in employment policy which is not based on explicit statutory authorization. ${ }^{145}$ Further, major portions of procurement regulations reflect policies of the department or agency issuing them, policies, it might be observed, which are not all referable to the specific content of any statute. ${ }^{146}$

It might be helpful to attempt a rough grouping of the sorts of statutes that can be relied on to support procurement regulations:

(a) Those which lay down substantive rules for implementation. Included under this head, for example, might be the Walsh-Healey Act, the Davis-Bacon Act, ${ }^{147}$ the Contract Work Hours Standards Act, ${ }^{148}$ the "Emergency Contract Authority Act," 149 the Armed Services Procurement Act, and the Federal Property and Administrative Services Act. ${ }^{150}$

1104 I C.F.R. $\$$ I8-r.IOI.

161 The Armed Services Procurement Act applies to NASA, Io U.S.C. $\$ 2302$; see note I06 supra.

162 II C.F.R. $\$$ I8-T.Y02.

${ }^{143}$ E.g., FPR $\$ I-12.6,4$ I C.F.R. Subpart I-I2.6.

1"Sec NASA PR 12.603 .

${ }^{165}$ See NASA PR $12.80 \mathrm{I}-\mathrm{2} 2.802$ implementing the Nondiscrimination in Employment policy, supra notes $28,29,30,31,32,33,34$.

${ }^{260}$ E.g., the "Termination for Convenience" regulation and clauses in NASA PR Part 8, FPR I-8, 4I C.F.R. Part I-8. At one time the Contract Settlement Act of I944, 4I U.S.C. \$\$ roI-25 would have supported the Termination for Convenience provisions, but it applied to "war" (i.e., World War II) contracts and subcontracts, $\S_{3}(\mathrm{c})$, 4 I U.S.C. $\S$ I03 $_{3}$ (c). It would be rather hard, in any event, to infer that this act applies to NASA, which was created in 1958 .

${ }^{147} 40$ U.S.C. $\$ \$ 276 a-276 a-5$.

${ }^{248} 76$ Stat. 357 (1962), 40 U.S.C. $\$ \$ 327-32$.

${ }^{140} 50$ U.S.C. $\$ \$ 1431-35$.

1804 II U.S.C. $\$ \$ 25 \mathrm{I}-60$. 
(b) Those which simply authorize the issuance of regulations such as section 203 (b) (x) of the Space Act, or the so-called "housekeeping act." A special type of statute within this category is section 206(a) (4) of the Federal Property and Administrative Services $A c t^{151}$ authorizing the General Services Administrator to prescribe standardized forms, procedures, and purchase specifications. Although these comments were probably directed to the regulatory agencies, K. C. Davis says about administrative regulations $:^{152}$

The distinction between interpretative rules and legislative rules is an essential part of our system, even though the Supreme Court has never provided a full-bodied discussion of it. A legislative rule is the product of an exercise of legislative power by an agency, pursuant to a grant (whether explicit or not) of legislative power by the legislative body; a court will no more substitute judgment on the content of a valid legislative rule than it will substitute judgment on the content of a valid statute. A legislative rule is valid if it is (a) within the granted power, (b) issued pursuant to proper procedure, and (c) reasonable.

Interpretative rules are rules which do not rest upon a legislative grant of power (whether explicit or inexplicit) to the agency to make law. Interpretative rules usually interpret the statute, but sometimes they properly go beyond the statute, and when they do they are still called interpretative rules even though they are not interpretative in the literal sense. Interpretative rules have all degrees of authoritative weight, varying from an approximation of zero to full force of law, depending upon (a) the degree of the court's agreement or disagreement with the rule, (b) the extent to which the subject matter is within special administrative competence and beyond general judicial competence, (c) whether the rule is a contemporancous construction of the statute by those who are assigned the task of implementing and enforcing the statute, (d) whether the rule is one of long standing, and (e) whether the statute has been re-enacted by legislators who know of the content of the rule.

Keeping in mind the fact that there is no general congressional statute authorizing in explicit fashion the issuance of procurement regulations which are to bind the public, it would seem that Professor Davis' analysis would be helpful in assisting us to reach some decision about the effectiveness of a given regulation. Thus, we would look to the statute on which a regulation appears to be based in deciding whether that regulation can be ascribed a "legislative" character and subject, therefore, to a minimal judicial scrutiny or an "interpretative" character and so subject to more rigorous scrutiny. But even this analysis would not help us in all cases in deciding the radical question of the group of persons who are bound by the regulations. It possibly might be easy to conclude that contractors are subject to regulations issued under the Walsh-Healey Act even though their contracts did not contain the clause required by the act, ${ }^{153}$ the ground being that congressional policy

${ }^{25 x} 40$ U.S.C. $\$ 487$ (a) (4) (I958); and see $\$ 205$ (c), Federal Property and Administrative Service Act, 40 U.S.C. $\$ 468(\mathrm{c})$ (1958) authorizing the GSA Administrator to issue regulations necessary to "effectuate his functions" under the act.

${ }_{152}$ I Kenneth C. Davis, Administrative Law Treatise $\$$ 5.1x, at 358 (1958).

${ }^{153}$ See United States v. Smoler Bros., Inc., I87 F.2d 29 (7th Cir. 195I), where the clause used in the contract deviated from the terms required by the Walsh-Healcy Act. The court held that the terms in the contract, not those required by the statute, governed. See also Note, 51 GEo. L.J. $842,847-48$ (1963). 
was strong enough to extend that far. But in the case of a regulation which can be premised only on a statute like the "housekeeping act," or section 2202 of title ten, or even section 203 (b) (I) of the Space Act, no clear-cut congressional intent seems to be available. One can, of course, make the almost certain inference that Congress intended regulations under such authorities to be binding within the departments or agencies to which the statutes relate. But even if we assign such regulations "legislative" force in terms of Professor Davis' category, it is logically very risky to infer that they have such force on contractors with such agencies. True enough, contractors may subject themselves to regulations, but even the regulations seem to contemplate that this be done as a contractual act, i.e., by incorporation of the regulations in the contract at the time the contract is made. Thus, for example, NASA Procurement Regulation 15, which relates to the cost principles applicable to costtype contracts, provides for incorporation by reference of the specific principles applicable. ${ }^{154}$

The NASA "Termination for Convenience" clause referred to above, is not premised on any explicit statutory authority. The Armed Services Procurement Act which governs NASA purchasing procedures makes no reference to termination of contracts. It should be remembered that the Supreme Court in the Paul case, ${ }^{155}$ expressed the view that the Armed Services Procurement Regulation, based on the Armed Services Procurement Act, had the force and effect of law. But the Court, in that case, was speaking of a portion of the ASPR which implemented specific provisions of the act commanding price competition. At one time there was a statute, the Contract Settlement Act of $1944,{ }^{156}$ which did govern the subject of termination for convenience; but this statute applied to "war" contracts and subcontracts (that is, World War II) ${ }^{157}$ and it seems unnecessary to say that NASA (established in $195^{8}$ ) made none of these contracts. In general, that statute is not applicable to any department or agency, except as to "war" contracts and "subcontracts." 158 It would seem, then, that the "Termination for Convenience" clauses in NASA Procurement Regulation, those in the Armed Services Procurement Regulation, ${ }^{150}$ and those in the Federal Procurement Regulation ${ }^{160}$ (all of them ultimately are patterned after ASPR) can be regarded as included in contracts against the will of the contractor only if regulations issued under general authorities such as those mentioned previously have the force and effect of law and are ipso facto

\footnotetext{
154 At the time of this writing NASA PR follows the Armed Services Procurement Regulation as far as cost principles are concerned. NASA PR I5.150-2(a) requires incorporation of the appropriate set of cost principles from ASPR sec. XV in NASA contracts of the cost-type. ASPR itself contemplates the same incorporation by reference, ASPR 15-102, as does the Federal Procurement Regulation, FPR S I-I5.I02, 4I C.F.R. \$I-I5.I02.

105 Note 129 supra.

${ }^{160}$ Note 146 supra.

157 lbid.

${ }^{168}$ Ibid. Perhaps the Court of Claims takes the opposite view: see Oliver-Finnie Company $\mathrm{v}$. United States, 279 F.2d 498 (Ct. Cl. I960).

${ }^{160}$ ASPR 8-701-8-706.

${ }^{100}$ FPR $\$$ I-8.70I-I-8.706, 4I C.F.R. \$\$I-8.70I-I-8.706.
} 
binding on contractors. To give them such force and effect, without clear-cut congressional sanction and without submitting the regulations, further, to the test of the Davis analysis, seems unwarranted.

Arthur John Keeffe put it in his own inimitable way when he said (about the Christian case) : ${ }^{161}$

[Judge] Oscar Davis may by this decision revolutionize Government contracting. Why have any contract at all? Shall we just write a contractor and say, we give you the job pursuant to all the appropriate regulations and in accordance with the way the Government does business?

He might have added: "We can wait until litigation to determine what the terms of your contract are." All of this seems a long way from the concept of bargain and it seems very close to a tolerance of a degree of executive government not contemplated by the Constitution. Nor does it in general accord with what I have assumed from experience to be the general intention of those in the executive departments and agencies who draft regulations which require the use of contract clauses. It does not seem to be the attitude of the National Aeronautics and Space Administration that clauses required by the NASA Procurement Regulations are for that reason included in contracts in cases where the bargain has not included them. I feel no hesitation in saying that the present generation of government officers and employees have no aspiration to achieve decisive control over contractors through "contract by regulation," but this is not to say that a hard-pressed future generation of government personnel may not yield to the latent temptation to tyranny. If the Court of Claims' position in the Christian case is indeed to prevail, then it would seem that a thorough review of the way in which procurement regulations are made is in order. As a minimum check, one would think that the "notice of proposed rule-making" provisions of the Administrative Procedure Act should be applied to contract regulations. ${ }^{162}$

\section{Some Other Cases}

There are other examples of "in house" legal problems-problems involving the "law of public administration" and pertaining to government contracts although not necessarily to litigation. I should like to mention some of these problems for the purpose of giving the reader a fair sampling of this area.

(a) Clauses relating to the Hebert Act: examination of contractors' and subcontractors' records. The Hebert Act was enacted in rg62. ${ }^{103}$ One of its main purposes was to provide additional controls over contract pricing by those departments and agencies (the Departments of Army, Navy, and Air Force, the National Aeronautics and Space Administration, and the Coast Guard) which conduct procurement under the Armed Services Procurement Act. ${ }^{104}$ Without going into

${ }^{101}$ Keeffe, Practicing Lawyer's Guide to the Current Law Magazines, 49 A.B.A.J. 1225, 1226 (1963). $102 \$ 4,5$ U.S.C. $\$ 1003$.

${ }^{103}$ Pub. I. $87-653,76$ Stat. 528-29 (I962). For some of the background of the act, see text, stupra, at notes $82-88$.

104 10 U.S.C. $\$ 2303($ a), as amended. 
the merits of the Hebert Act or the details of the mechanisms by which it was intended to be carried into effect, it can be pointed out that it was a practical necessity for the agencies subject to the act to gain access to contractors' and subcontractors' books and records to the extent necessary to execute the pricing policy set out in the act. The act does not specifically command that such access be obtained. The device used to insure that pertinent books and records will be available from contractors and subcontractors are contract and subcontract clauses. ${ }^{165}$

Access to contractors' and subcontractors' books and records is already provided by other statutes. Without any attempt to observe detail closely, we might note:

(i) Io U.S.C. $\$ 23{ }^{13}(a)$ which permits departments and agencies contracting under the Armed Services Procurement Act to inspect the plant and audit the books and records of contractors performing cost or cost-plus-a-fixed-fee (CPFF) contracts under the act and also to inspect the plant and examine the books and records of subcontractors performing subcontracts under such cost or CPFF prime contracts.

(ii) Io U.S.C. $\$ 23 \mathrm{I}_{3}$ (b) and 4I U.S.C. 3254 (c) providing for inclusion of a contract clause in negotiated prime contracts which will allow the Comptroller General or his representatives to examine certain pertinent books and records of the prime contractor and any of his subcontractors for a period of three years after final payment. $^{100}$

Presumably such books and records will already be subject to examination by the Commissioner of Internal Revenue under the Internal Revenue Code. ${ }^{167}$ Relevant and related reports may also presumably be asked for by the Bureau of the Census ${ }^{168}$ and the tradition is that census responses are confidential. ${ }^{169}$ In cases subject to the Renegotiation Act, the Renegotiation Board may also have the right to examine books and records of contractors and subcontractors. ${ }^{170}$

Without going into the cognate areas of records retention requirements of the federal government ${ }^{171}$ and the costly reporting requirements existing under some

\footnotetext{
${ }^{105}$ See ASPR 7-104.41, 7-104.42, 32 C.F.R. $\$ 7.104-1,7.104-42$. ASPR 7-r04.42 contains "flowdown" provisions for subcontracts. See also NASA PR 3.807-4(c), (d), (e) (effective Feb. I, I964).

${ }^{100} \mathrm{Sec}$ ASPR 7-104.15; NASA PR 7.104-15, 4I C.F.R. \$ 18-7.104-15. These clauses reflect the requirement of ro U.S.C. $\$ 2313$ (b) for fixed-price supply contracts. The substantially identical requirements of 4 I U.S.C. $\$ 254$ (c) are reflected in FPR $\$$ I-7.IOI-IO, 4I C.F.R. $\$$ I-7.Ior-Io (also for fixed-price supply contracts).

${ }^{107}$ INT. REv. CODE of 1954, $\$ 7602$. See also INT. REv. Code of 1954, $\$ 7213$. As to the availability of tax returns to federal agencies, see INT. REv. CODE of I954, \$6ro3, and 26 C.F.R. $\$ 30 x-6$ ro3. Implementation by executive order (as authorized by $\$ 6 \mathrm{I0}_{3}$ ) can be found in Exec. Order No. x0906, 26 Fed. Reg. 508 (196I), as amended by Exec. Order No. I0954, 26 Fed. Reg. 6759 (I96r). A series of executive orders relating to availability of tax returns to various committees of Congress can be found listed following 26 U.S.C.A. $\$ 6 \mathrm{ro3}_{3}$ (Supp. I963).

${ }^{108}{ }_{13}$ U.S.C. $\$ 13 I$.

${ }^{100}$ The St. Regis Paper Company learned (presumably to its surprise) that although the copy of a report it filed with the Census Bureau might be privileged against disclosure to other government agencies under 13 U.S.C. $\S 9$, its own retained copy of the report could be obtained from it by court order at the request of the Federal Trade Commission. St. Regis Paper Co. v. United States, 365 U.S. 857 (rg6r). 13 U.S.C. $\$ 9$ was amended to preclude this result, Pub. L. 87-813, 76 Stat. 922 (1962).

${ }_{170} \S 105(c)$, Renegotiation Act of I95I, as amended and extended, 50 U.S.C. App. $\$ 1215(c)$.

171 A good idea of the scope of records keeping requirements imposed by the federal government can be obtained from the annual "Guide to Records Retention Requirements" published in the Federal Register. Sec, e.g., 29 Fed. Reg. No. 45, Part II (March 5, I964).
} 
federal contracts, ${ }^{172}$ it is not too difficult to conclude that the operations of the federal government must be a major boon to the data processing and information retrieval industries. What begs for inquiry by the executive or the legislative branch is the subject of whether all of this can be simplified. Could some fairly elaborate but all-purpose set of reports be devised which would suffice for all legitimate government purposes? I do not mean to underemphasize the word "legitimate." Knowledge in its way is power and a fit subject for inquiry ought to be whether the government is on its way to too much power by means of acquiring too much information.

(b) "Contracting Out." This strikingly named topic has already been the subject of one law review symposium, ${ }^{173}$ has been analyzed in one Bureau of the Budget report, ${ }^{174}$ and has been scrutinized by two congressional committees. ${ }^{176}$ At the bottom, concern over contracting out is a concern over whether certain governmental tasks (such as evaluating performance of contractors, and advising as to a wide range of policy choices) can be permissibly placed in the hands of contractors, even nonprofit contractors fairly closely supervised by the government such as the Rand Corporation or Aerospace, Inc. The problem involves a dilemma based on the fact the government could itself provide such services if it were permitted to pay higher salaries to selected specialists and if it would create more desirable working

${ }^{172}$ For an example of a report, see DD Form II40-I, ASPR Appendix "F," I F-200,1 I40-I (Defense Small Business Subcontracting Monthly Report of Participating Large Company on Subcontract Commitments to Small Business Concerns). This report is required by a contract clause, ASPR I-707.3(b) included in a regulation, ASPR $1-707$, which reflects the requirements of the Small Business Act $\$ 8$ (d), as added by $\$ 7$, Small Business Act Amendments of $196 \mathrm{r}, 75$ Stat. 667-68 (1961), I5 U.S.C. $\$ 637$ (d). Similar requirements may be found in FPR $\S_{I-1.710,4}$ I C.F.R. $\S_{I-I .710}$ and in NASA PR 1.70\%. Additional reporting requirements exist, of course, and it would be beyond the scope of this note to trace them. Suffice it to say that the cost of reporting requirements (much of which is borne by the government itself in the form of contract costs) was great enough to cause Secretary of Defenee McNamara to ask the assistance of the National Security Industrial Association in preparing recommendations which would help reduce reporting requirements. The recommendations of Task Committee No. 5 on the subject of "Streamlining Administrative Reporting Requirements" are found at pp. I03-II of "Report of Cost Reduction Study" prepared by the Cost Reduction Task Force of the NSIA Procurement Advisory Committee for submission to the Secretary of Defense, dated June 15,1962 . (Publ. by NSIA, I I07 Igth St., N.W., Washington 6, D.C.). In a report prepared by Senator Smathers' Military Procurement Advisory Committee, How to Improve Federal Procedures for Buying National Defense Materials, the Committee stated (at p. 38) that at a conservative estimate, the total man hours required to be spent on federal reporting for 1960 would be in excess of two and one-quarter million. The report further commented (ibid.) that the Committee had learned that one company would spend approximately $\$ 300,000$ in making a special cost study report to the military departments. According to the Committee (ibid.) the Aerospace Industries Association's ten largest companies had cstimated that they spent over $\$ 100,000,000$ per year on administrative reports to the military services. [This report is dated Aug. I $8,196 \mathrm{r}$, and was not generally distributed as far as I know.]

${ }^{173}$ Administration by Contract: An Examination of Governmental Contracting Out, $3 \mathrm{I}$ GEo. Wastr. L. REv. $685-784$ (1963).

${ }^{174}$ U.S. Bureau of the Budget, Report to the President on Government Contracting for Research and Development (the Bell Report), S. Doc. No. 94, 87th Cong., 2d Sess. (1962). It was also published in Hearings Before a Subcomm. of the House Government Operations Comm. on Systems Development and Management, 87th Cong., 2d Sess., pt. I, App. I (1962).

${ }^{175}$ A Subcommittee of the House Government Operations Committee held hearings on Systems Development and Management in 1962 [87th Cong., 2d Sess., pts 1-5] and in 1963 [88th Cong., rst Sess.]. See also Hearings on Contracting-Out Procedures Before the Subcommittee for Special Investigations of the House Armed Services Committee, 87th Cong., rst Sess. (I96r). 
conditions for such people. For the lawyer, an intriguing question lies in the background: does the delegation of tasks to "contractors out" ever involve the devolution of part of the "executive power" of the United States ${ }^{176}$ on private organizations? Despite Corwin, ${ }^{177}$ much remains to be done by way of analysis of that term.

(c) Interdepartmental Cooperation. One of the most interesting phases of executive operations is the cooperation between two or more departments or agencies in the conduct of a project or program which is the general responsibility of the executive branch. Readers of this who were following events in $195^{8}$ will remember the public discussion surrounding the creation of the National Aeronautics and Space Administration. One problem was felt to be crucial: Should United States space activities be placed under the predominant control of a civilian or a military agency ? $^{178}$ The end result was a form of compromise: general responsibility and control were vested in the National Aeronautics and Space Administration except that the military and defense aspects of national space activity were to be under the direction of the Department of Defense. ${ }^{178}$ Obviously, cooperation between NASA and the Defense Department was implied just as was a problem: the definition of boundaries between the two branches of space activity. Two mechanisms were set up, the National Aeronautics and Space Council ${ }^{180}$ and the Civilian-Military Liaison Committee, ${ }^{181}$ to deal with cooperation and boundary-marking. While the latter is inactive, the former has increased its activities. Primarily the Council is in existence to advise the President on space problems and particularly to advise him on interdepartmental relationships. By an amendment to the Space Act in I96r, the President was divested of the chairmanship of and membership in the Space Council and the then Vice President (Mr. Lyndon Johnson) was appointed to membership and to the chairmanship. ${ }^{182}$ Although this change in the act was requested by the executive branch and, of course, approved by the President after enactment by Congress, it poses the fascinating legal question of whether legislation may appoint the Vice President to tasks within the executive branch, even when the character of those tasks is "advisory" in nature. ${ }^{183}$ Presumably the President's consent to the

${ }^{170}$ U.S. Const. art. II, $\$$ I.

${ }^{177}$ Edward S. Corwin, The President, Office and Powers (4th rev, ed. 1957).

${ }^{178}$ See H.R. Rep. No. I770, 85th Cong., 2d Sess. 6-7, I2-13 (1958); S. REP. No. r7or, 85th Cong., 2d Sess. 4, I2 (1958); H.R. REp. No. 2166, 85th Cong., 2d Sess. 15-16 (1958).

$170 \$$ ro2(b), Space Act, 42 U.S.C. $\$ 245 \mathrm{I}$ (b).

$180 \$ 201$, Space Act, as amended, 42 U.S.C. $\$ 247 \mathrm{r}$.

$181 \$ 204$ Space Act, 42 U.S.C. $\$ 2474$.

$183 \$ 201$, Space Act, as amended by Pub. L. $87-26,75$ Stat. 46 (I96r), 42 U.S.C. $\$ 247 \mathrm{r}$. The bill which became Pub. L. $87-26$ was recommended to Congress by the President. See S. REP. No. I74, 87 th Cong., Ist Sess. I (196r).

${ }_{183}$ This issue was raised in the hearings on the bill which became Pub. L. 87-26. See Hearings Before the Senate Committee on Aeronautical and Space Sciences on H.R. 6169, 87th Cong., Ist Sess. 5-7 (196r); and Hearings Before the House Committee on Science and Astronatutics, on H.R. 6169, 87th Cong., Ist Sess. 8-9 (I96r). The argument in favor of constitutionality of the provision was presented with considerable persuasiveness in a memorandum of then Assistant Attorney General Katzenbach reprinted in the Senate hearings, supre, at 5-8. The difficult point of whether it was wise thus to bind a future President (who might not want his Vice President on the Space Council) was raised in the House hearing, supra, at 23-24. Of course, no one thought to provide for what should be done in the 
legislation should be given weight in conjunction with the congressional enactment, the two constituting a practical construction of the Constitution. Fascinating also is the way in which cooperation between departments and agencies can be achieved. For example, very recently, NASA and the Department of Defense entered into an agreement covering "instrumentation ships" for tracking and data acquisition in connection with, inter alia, the Apollo program. The agreement was prepared by an ad hoc joint committee and then approved by the NASA Administrator and the Deputy Secretary of Defense. ${ }^{184}$ Stimulus for the agreement was provided by a requirement of the congressional.committee of conference on the NASA I964 Authorization Act ${ }^{185}$ that NASA and the Defense Department attempt to achieve agreement on the ships and that NASA present either the agreement or a report of inability to reach an agreement to the House and Senate Space Committees by January 15,1964 . Surely the agreement which was reached in some ways resembles a contract of compromise with a third and interesting party acting as broker. The interesting point is that the "third party" is in the legislative branch and that the President has not officially participated nor has the whole Congress acted as such. The practical appeal of such proceedings lies, of course, in the fact that an administrative problem has been disposed of with a maximum of cooperation between both branches.

\section{Concluston}

I have set forth some of the ideas and some of the legal events emphasizing areas of relevance to government contracts which have led me to believe that the "law of public administration" is worthy of study by lawyers and law teachers. I hope that I may have led the reader to share this belief. But any study of, and concern with, this subject can only be fruitful if there is some serious and sustained effort by way of a systematic analysis of the major government departments and agencies in their government contracts, their internal operations, and their relationships with one another and with the Congress. I would welcome advice and assistance.

case that actually happened, that is, in the case the President died in office and the Vice President succeeded him. The Constitution itself is not pellucidly clear on what happens to the Office of Vice-President in that event, and it does not provide for succession to it. U.S. CoNsT. art. II, $₹ \mathrm{I}, \mathrm{cl} .5$.

${ }_{184}$ NASA Management Manual 2-3-28 contains a memorandum summarizing the agreement. This memorandum was approved by the top officials named on Jan. 15,1964 .

${ }^{185}$ Pub. L. 88-II3, 77 Stat. I4I (I963). The requirement of the conference committec is found in the Conference Report, H.R. REP. No. 706, 88th Cong., Ist Sess. I0-xI (1963). 